\section{ÆUSGS}

science for a changing world

Fort Collins Science Center

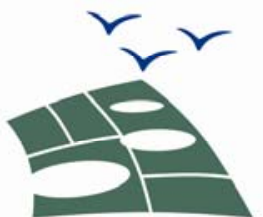

PLAYA LAKES JOINT VENTURE

\title{
Grass Buffers for Playas in Agricultural Landscapes: A Literature Synthesis
}

By Cynthia P. Melcher and Susan K. Skagen

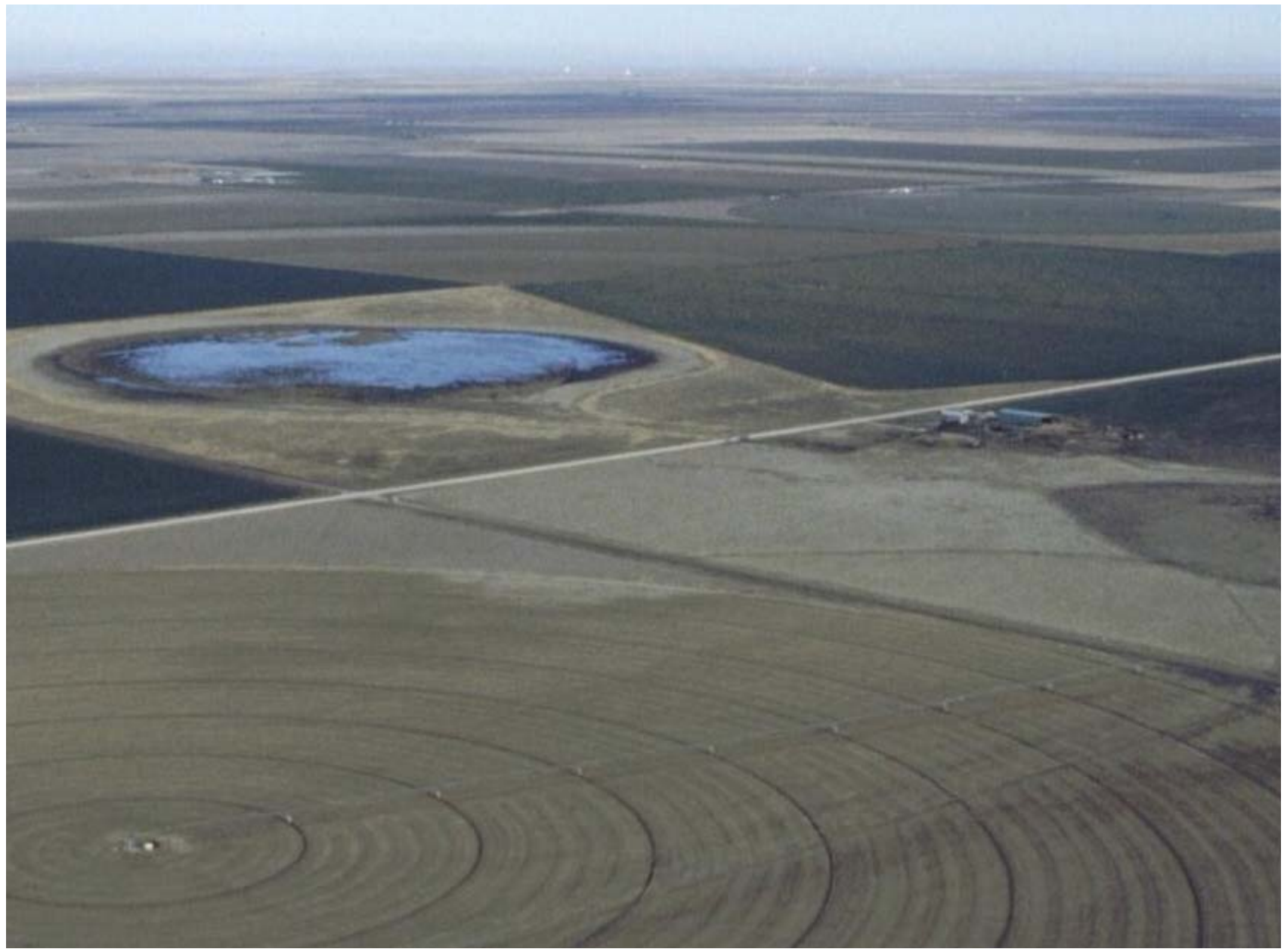

Open-File Report 2005-1220

U.S. Department of the Interior U.S. Geological Survey 
Cover photo courtesy of D.A. Haukos 


\section{U.S. Department of the Interior \\ Gale A. Norton, Secretary}

\section{U.S. Geological Survey \\ Charles G. Groat, Director}

\section{U.S. Geological Survey, Reston, Virginia 2005}

This Open-File Report is also available online at:

http://www.fort.usgs.gov/products/publications/21485/21485.asp

For product and ordering information:

World Wide Web: http://www.usgs.gov/pubprod

Telephone: 1-888-ASK-USGS

For more information on the USGS - the Federal source for science about the Earth, its natural and living resources, natural hazards, and the environment:

World Wide Web: http://www.usgs.gov

Telephone: 1-888-ASK-USGS

\section{Suggested citation:}

Melcher, C.P., and Skagen, S.K., 2005, Grass buffers for playas in agricultural landscapes: A literature synthesis: U.S. Geological Survey, Biological Resources Discipline, Open-File Report 2005-1220, $35 \mathrm{p}$.

Any use of trade, firm, or product names is for descriptive purposes only and does not imply endorsement by the U.S. Government

Although this report is in the public domain, permission must be secured from the individual copyright owners to reproduce any copyrighted material contained within this report. 


\section{Contents}

A Joint Project of the USGS and the Playa Lakes Joint Venture Monitoring, Evaluation, and Research

Team .

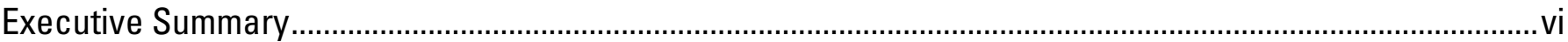

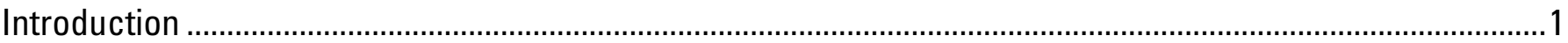

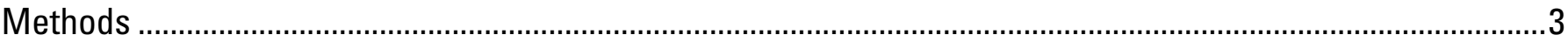

Results and Discussion ............................................................................................................................

Sediment and Contaminant Transport, Effects on Wetlands and Wildlife .....................................................

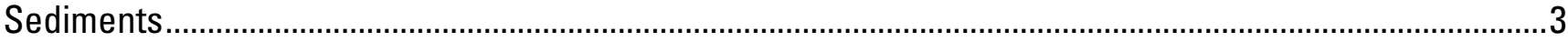

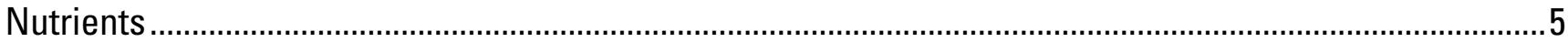

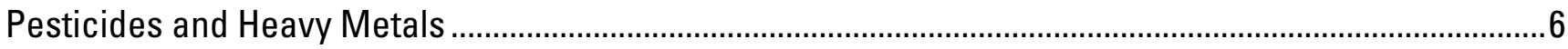

Potential Buffer Effects on Overland Water Flow.........................................................................................

Buffers: Design and Effectiveness, Models, and Management..................................................................10

Buffer Widths and Other Design Considerations ................................................................................11

Vegetative Structure and Species Potentially Useful for Playa Buffers ...................................................13

Models for Predicting or Evaluating Buffer Effectiveness ........................................................................ 14

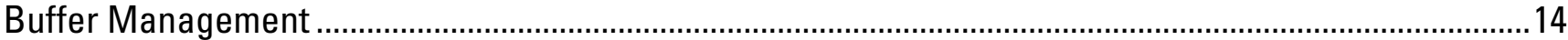

Avian Use of Grasslands As It May Relate to Playa Buffers .......................................................................

Avian Densities in Grass Buffers ..................................................................................................16

Avian Densities in CRP Fields of the Playa Lakes Region ...............................................................16

Buffer Effectiveness for Reducing Human Disturbance ..........................................................................18

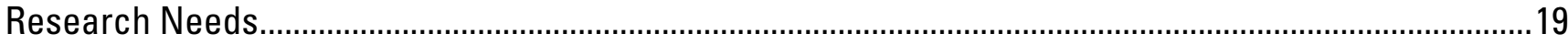

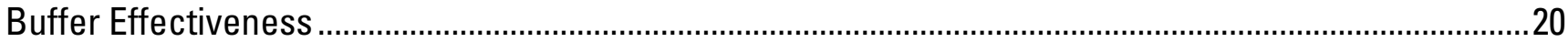

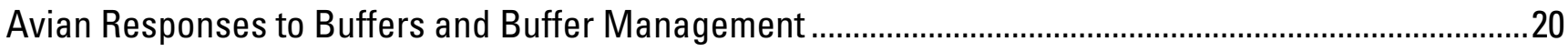

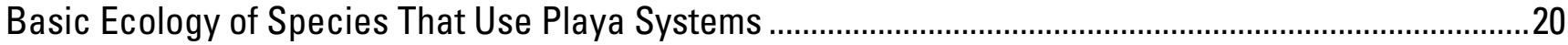

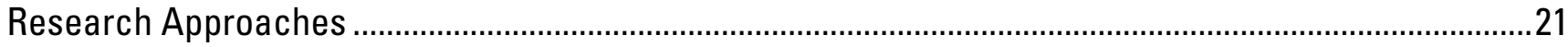

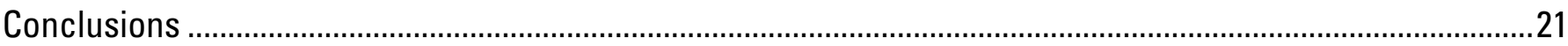

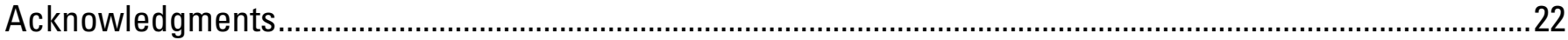

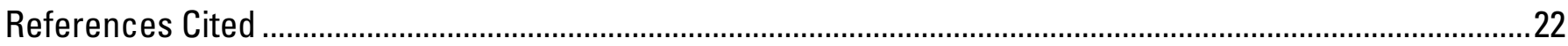

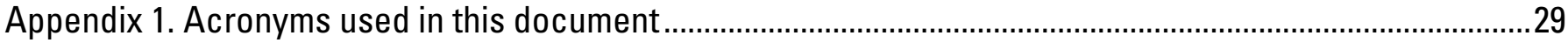

Appendix 2. Summary of selected buffer studies ……….............................................................................

\section{Figure}

1. Playa Lakes Joint Venture (PLJV) and Bird Conservation Region (BCR) boundaries 


\section{A Joint Project of the USGS and the Playa Lakes Joint Venture Monitoring, Evaluation, and Research Team}

Playa Lakes Joint Venture (PLJV) Monitoring, Evaluation, and Research Team:

$\begin{array}{ll}\text { Reggie Blackwell } & \text { U. S. Forest Service/Natural Resources Conservation Service } \\ \text { Alison Cariveau } & \text { Rocky Mountain Bird Observatory } \\ \text { Jim Dubovsky } & \text { U.S. Fish and Wildlife Service } \\ \text { Lee Elliott } & \text { The Nature Conservancy } \\ \text { Helen Hands } & \text { Kansas Department of Wildlife and Parks } \\ \text { Bill Johnson } & \text { Texas Parks and Wildlife } \\ \text { David Klute } & \text { Colorado Division of Wildlife } \\ \text { Ted LaGrange } & \text { Nebraska Game and Parks Commission } \\ \text { Keith McKnight } & \text { Ducks Unlimited } \\ \text { Tim Mitchusson } & \text { New Mexico Game and Fish Department } \\ \text { Lynn Nymeyer } & \text { U. S. Fish and Wildlife Service } \\ \text { Mike O’Meilia } & \text { Oklahoma Department of Wildlife Conservation } \\ \text { Jim Ray } & \text { BWXT Pantex, LLC }\end{array}$

PLJV Management Board:

Merlin Bartz

Ruben Cantu

Cindy Correll

Barth Crouch

Bill Dunn

Paul Gertler

Nancy Gloman

Mace Hack

Richard Hatcher

Rob Hosford

Mike Johnston

Joe Kramer

Bob McCready

Ross Melinchuk

Jeff Ver Steeg

\section{PLJV Staff:}

Mike Carter

Karin Callahan

Christopher Rustay

Debbie Slobe

Brian Sullivan*

*PLJV liaison to USGS for this project.
Natural Resources Conservation Service

Texas Parks and Wildlife

U. S. Forest Service

Pheasants Forever

New Mexico Game and Fish Department

U. S. Fish and Wildlife Service

U. S. Fish and Wildlife Service

Nebraska Game and Parks Commission

Oklahoma Department of Wildlife Conservation

Farm Services Agency

ConocoPhillips

Kansas Department of Wildlife and Parks

The Nature Conservancy

Ducks Unlimited

Colorado Division of Wildlife
Coordinator

GIS Team Leader

Shortgrass Prairie Bird Conservation Region Coordinator

Communications Team Leader

Biological Team Leader 


\section{Executive Summary}

We summarize current knowledge about grass buffers for protecting small, isolated wetlands in agricultural contexts, including information relevant to protecting playas from runoff containing sediments, nutrients, pesticides, and other contaminants, and information on how buffers may affect densities and productivity of grassland birds. Land-uses surrounding the approximately 60,000 playas within the Playa Lakes Region (PLR), including intensive agriculture, feedlots, and oil extraction, can contribute to severe degradation of playas. Farming and grazing can lead to significant sedimentation in nearby playas, eliminating their ability to hold water, support the region's biodiversity, or adequately recharge aquifers. Contaminants further degrade habitats and threaten the water quality of underlying aquifers, including the Ogallala Aquifer.

Grass buffers hold promise as a management tool to reduce the amount of sediments and contaminants from agricultural runoff that enters playas. Effective buffer width is determined by acceptable sediment-reduction levels, potential water flow and velocity, landscape and soil variables, buffer species, and vegetation structure. Various models have been developed to predict buffer effectiveness; however, most of these models, including those provided by the Natural Resource Conservation Service (NRCS), remain unvalidated. The majority of buffer-effectiveness literature is based on simulated conditions in experimental trays or plots; no published studies of buffer design or effectiveness specifically address playas. Nonetheless, some general patterns have emerged regarding buffer design/effectiveness.

Buffers 10-60 m wide are generally considered adequate for trapping most sediments, although in some cases buffers need to be $>200 \mathrm{~m}$. The U.S. Fish and Wildlife Service Partners for Wildlife Program in the Southern High Plains recommend a buffer width of $\sim 33$ m planted with a diverse mix of native shortgrasses and mixed grasses as a starting point. Most dissolved contaminants, however, are removed from runoff only when they infiltrate the soil, where microbes or other processes can break down or sequester contaminants. Promoting runoff infiltration requires wider buffers with denser stem densities than those required for filtering sediments, which may result in hydrological changes in playas. Ultimately, the balance between runoff and infiltration determines whether or not water eventually reaches a given basin. Long-term buffer effectiveness requires regular maintenance, including excavation to remove overburdens of sediments, repairing vegetation damage, and removing over-mature vegetation or invasions of noxious weeds.

Buffers may not be enough to protect playas; best management practices (BMPs; e.g., conservation tillage, contour tilling, and mulching herbicides into soil after application) that diminish soil erosion and contaminant runoff also may be necessary. Nutrient loads in runoff can be minimized by balancing nutrient input with nutrient requirements for livestock and crops. Pesticide application practices also require careful evaluation. Mowing or grazing rather than use of herbicides offer alternatives for suppressing invasive or undesirable plant species in buffers.

Future research should entail multiple-scale approaches at regional, wetland-complex, and individual watershed scales. Information needs include direct measures of buffer effectiveness in 'real-world' systems, refinement and field tests of buffer-effectiveness models, how buffers may affect floral and faunal communities of playas, and basic ecological information on playa function and playa wildlife ecology. Understanding how wildlife communities respond to patch size and habitat fragmentation is crucial for addressing questions regarding habitat quality of grass buffers in playa systems. 


\title{
Grass Buffers for Playas in Agricultural Landscapes: A Literature Synthesis
}

\author{
By Cynthia P. Melcher and Susan K. Skagen, U.S. Geological Survey
}

\section{Introduction}

Playas are isolated, relatively small recharge wetlands, the distribution of which corresponds closely with the Ogallala Aquifer in eastern New Mexico, northwestern Texas (including the panhandle), the Oklahoma panhandle, western Kansas, eastern Colorado, western and southern Nebraska (including the Rainwater Basin), and southeastern Wyoming. There are approximately 60,000 playas throughout the playa lakes region (PLR; Playa Lakes Joint Venture, unpub. data); at least 25,000 of these occur in the Southern High Plains (SHP; Haukos and Smith, 2003; Fig. 1).

Most playas are catchment basins in relatively small watersheds with no external drainage. Playa hydrology is characterized by cycles of inundation and drying out; some playas remain dry for years. When rain does fill them, some remain wet for just a few months and others may remain wet for years (Curtis and Beirman, 1980). Wet or dry, all playas are characterized by hydric soils and relatively impermeable basin floors of clay, which allow them to retain water.

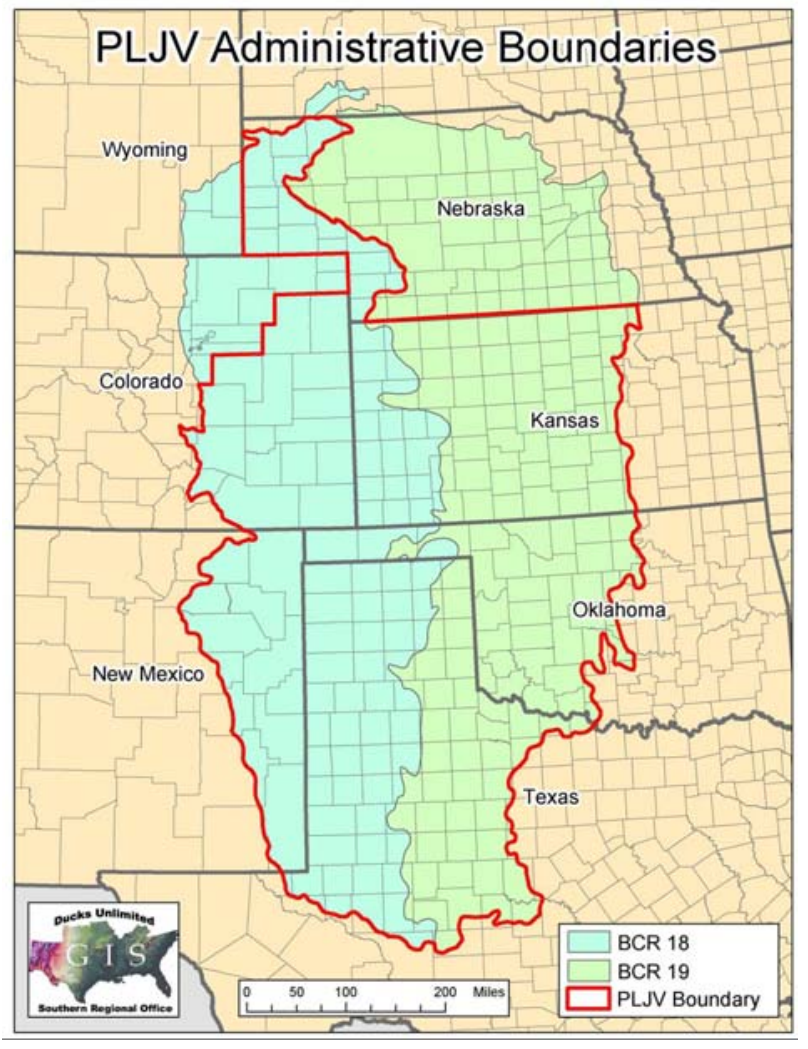

Figure 1. Playa Lakes Joint Venture (PLJV) and Bird Conservation Region (BCR) boundaries. The Southern High Plains roughly corresponds with the lower of half of BCR 18, including southeastern Colorado and southwestern Kansas. 
Playas serve as major recharge foci for the Ogallala Aquifer (Zartman and others, 1994). Although the relationship between playas and Ogallala recharge still requires more research, there is increasing evidence that most infiltration from playa basins occurs within the first 1-3 days of inundation (Zartman and others, 1994). As the clay soil of a playa dries, large cracks (macropores) form across the basin floor; at least in the SHP, dissolution processes create additional macropores within the underlying caliche (a relatively impermeable layer of soil particles cemented together by carbonates). When water inundates the dry playa, water passes through the macropores to subsurface regions and eventually to the Ogallala Aquifer. As basin soils become saturated, the clay swells, effectively sealing the macropores and diminishing infiltration rates (Zartman and others, 1994). If a playa's water level rises high enough, water also may seep through the basin edge, or annulus, or even infiltrate soils outside the basin itself (Zartman and others, 1994).

As much as $50 \%$ of the Ogallala's recharge may result from infiltration in upland soils, but the remaining 50\% likely infiltrates through playa basin floors and annuli (Wood and Sanford, 1994). Because playas cover only 2-6\% of the entire land area (Wood and Sanford, 1994; Haukos and Smith, 2003), the proportion of recharge from a given area of playa is far greater than it is from the same area of upland. If these recharge foci are degraded or even eliminated due to sedimentation, a corresponding decline in aquifer recharge may occur as well. Most playas occur in a context of croplands, feedlots, and/or rangelands, from which sediments may be carried into the playas in precipitation and irrigation runoff. Indeed, many playas are already completely or nearly filled in by sediments (Luo and others, 1997, 1999).

Nonpoint source pollution from agricultural runoff and direct dumping of wastes further degrades playas. In the High Plains of Texas, no playas are free of contaminants, including nutrients from chemical fertilizers, feedlot runoff and manure fertilizers, urban wastewater, wastes from petroleum-extraction activities, pesticides (herbicides, insecticides, fungicides, etc.), and heavy metals (Irwin and others, 1996). Even playas surrounded by relatively undisturbed grasslands contain contaminants from pollutants carried on wind-borne sediments, drift from aerial spraying, and herbicides used to eliminate woody plants from rangelands.

As a result of their water-holding capacity in an otherwise semi-arid region, playas support an impressive diversity of flora and fauna (Bolen and others, 1989; Haukos and Smith, 1994; Hoagland and Collins, 1997). Many plant species occur exclusively in playas (Reed, 1930). Playas also provide crucial winter habitats for waterfowl and cranes, migration stopover habitats for waterbirds and shorebirds, and breeding habitats for waterfowl, grassland raptors, shorebirds, and passerines (Curtis and Beirman, 1980; Nelson and others, 1983a; Davis and Smith, 1998; see summary in Smith, 2003, p. 78-102). Without functional playas of all sizes and hydrological regimes throughout the playa region, the biodiversity they support is at grave risk of being lost (Anderson and Smith, 2000; Haukos and Smith, 2003). Recently, federal, state, and private funding has been made available for buffering playas to protect them from sedimentation and pollution while simultaneously enhancing wildlife habitat. Grass buffers hold promise as a management tool to reduce the amount of sediments and contaminants in the agricultural runoff that enters playas.

There are a number of synonymous, or nearly synonymous, terms that describe grassed wetland buffers, including buffer, vegetated filter strip (VFS), grass buffer, grass filter, grass hedge, grassed waterway (GW), and others (McKague and others, 1996). Although some terms represent slightly different designs, placements, or purposes, these structures all perform similar functions. In this document, we use 'buffer' and VFS interchangeably; other types are specified by name (e.g., grass hedges). We define grass buffer or VFS as an area of grass vegetation placed between a wetland and a source of potentially damaging runoff.

Buffers are herbaceous, woody, or both, and generally $>20 \mathrm{~m}$ to $>100 \mathrm{~m}$ wide. A VFS is a vegetative barrier usually placed on the downslope edges of a potential source of runoff; occasionally, however, VFSs may be placed either singly or in bands farther upslope to keep soils from being 
transported off croplands. VFSs are generally herbaceous and relatively narrow (1-25 m). Grass hedges are similar to VFSs, although most are very narrow $(0.3-1.0 \mathrm{~m})$. The hedges are planted with tall grass at great stem densities in bands along slope contours to hold soils in place on steeper slopes and/or where wind erosion is significant (Van Dijk and others, 1996). Other types of buffers are not considered herein. A brochure published by the National Buffer Conservation Team contains fairly precise definitions of buffer types in federal and state programs (U.S. Department of Agriculture, 2000).

Acronyms used in this document are defined in Appendix 1.

\section{Methods}

To develop this synthesis, and the associated bibliography (Melcher and Skagen, 2005), we conducted extensive searches of existing literature and sought professional knowledge from scientists and land managers. Literature searches entailed the use of databases, such as Agricola, Cambridge Scientific Abstracts (including agricultural, biological, ecological, environmental, pollution and engineering topical areas), Water Resources Abstracts, Wildlife Worldwide (NISC), First Search, Web of Science (Science Citation Index), Dissertation Abstracts, and others. We also made significant use of existing buffer/VFS reviews and bibliographies, as well as the bibliography sections of publications that we reviewed for this bibliography. A.W. Allen (U.S. Geological Survey, Fort Collins, $\mathrm{CO}$ ) generously provided us with a bibliography that he is developing on the effects of the Conservation Reserve Program (CRP) with respect to wildlife habitat, habitat management in agricultural systems, and agricultural conservation policy.

In addition to literature searches, we conducted keyword searches in library catalogues (U.S. Geological Survey's FORT Science Center library, Colorado State University's Morgan Library, and Colorado Prospector libraries), making use of interlibrary loan services to access potentially important publications not available locally. We also conducted keyword and citation searches on the World Wide Web using <http://www.scholar.google.com>; many publications and general sources of information (including information from the Natural Resources Conservation Service [NRCS]) were easily found and accessed this way. Finally, we interviewed numerous individuals, including researchers, land managers, and others with expertise on topics relevant to this bibliography and synthesis, requesting reprints from them when their publications were not readily accessible by other means.

\section{Results and Discussion}

\section{Sediment and Contaminant Transport, Effects on Wetlands and Wildlife}

An overall wetland-protection strategy requires a basic understanding of the processes that affect wetlands and buffers (Mitchell, 2002). Therefore, this section summarizes the sources, dynamics, and effects of runoff threats to playas, especially those that may be mitigated by buffers and other best management practices (BMP). It provides a basic framework for assessing buffer need, design, and potential effectiveness.

\section{Sediments}

The single greatest runoff-associated threat in nearly every playa is sedimentation. Several landscape- and watershed-scale factors affect rates of sedimentation. Typically, sedimentation occurs at faster rates in regions of greater slope and coarse- or medium-textured soils. Luo and others (1997, 1999) have found that this holds true in the SHP, where there is a northeast-to-southwest gradient in soil texture from fine to medium, respectively (see Dvoracek, 1981, p. 73, fig. 1). Land use also affects sedimentation, with more occurring in cropland playas, although sedimentation can occur in 
rangeland playas due to overgrazing (Luo and others, 1997, 1999). Within the SHP, cropland dominates regions of fine-textured soils, whereas rangeland typically dominates the coarser soils (Nelson and others, 1983a). Thus, even though row-crops promote more erosion, the coarser soils of rangelands are more erodable, complicating regional patterns of sedimentation.

Soil erosion is also a function of pre- and post-harvest residue, soil management, irrigation techniques, stem density, and percent vegetation cover (Sprague and Triplett, 1986; Eghball and others, 2000). No-till methods usually provide greater protection from soil erosion than disking or other forms of tillage (e.g., Mickelson and others, 2001). Crops commonly grown in the PLR are corn, grain sorghum, winter wheat, and cotton (Nelson and others, 1983a,b). Wheat typically forms a greater stem density than most other crops during the growing and post-harvest seasons, and postharvest wheat is typically left as stubble. Cotton, however, is planted at relatively minimal stem densities, and post-harvest fields are often disked or mulched (Sprague and Triplett, 1996; Mickelson and others, 2001).

Some sediments accumulated in playas may be scoured away by wind, although not enough to compensate for recent rates of sedimentation driven by anthropogenic factors (Luo and others, 1999). Some scientists believe that playas may have been formed or maintained by wind deflation (Smith, 2003). D. Gitz (oral commun., 2005) noted that the $70 \mathrm{mph}$ winds common to the SHP are more than adequate to transport sand and smaller particles away from playa basins; the formation of lunettes (dune-like deposits) on the edges of playas are evidence of this process (Smith, 2003). In playas of southwestern Nebraska, where wind velocities can also reach hurricane force, J. Jasmer (oral commun., 2005) has observed unvegetated playa basins deflated by up to one inch in a single winter. If vegetation in a playa basin or buffer shelters the basin from wind scouring, sedimentation problems could be exacerbated. Indeed, grass hedges are often installed to reduce wind erosion of topsoils from croplands (e.g., Black and Aase, 1988). Wind deflation warrants consideration when planning vegetation management for playa buffers and basins. Furthermore, some natural sedimentation of fine clay particles is likely what developed the clay linings of most playa basins; therefore, buffer vegetation that precludes even 'native' sedimentation processes could have long-term negative impacts on playa functions and ecology (see summary in chapter 2, Smith, 2003).

The factors described above affect sedimentation rates, volumes, and processes and may be controlled or altered through various BMPs, including buffers. The degree to which these factors play a role in sedimentation within a given playa or playa complex should be considered before buffers are implemented, as the degree of threat (thus the extent of buffering necessary) will vary widely throughout the PLR. For example, J. Jasmer (oral commun., 2005) indicated that in southwestern Nebraska typical rainfall patterns and local land use has not resulted in significant soil erosion; thus, playas in that region may need little to no buffering (or other BMPs may suffice). In the Rainwater Basin, however, sedimentation is a significant problem. Because the vast majority of playas throughout the PLR are on private land, it is the landowners who ultimately face long-term, economic consequences of productive land devoted to buffers and related BMPs (e.g., Boatman and Sotherton, 1988; Rickerl and others, 2000; but also see Stoecker and others, 1981; Bryant and Smith, 1988). Therefore, there is likely to be great interest in tailoring buffer widths and management from the perspectives of individual landowners.

Conservation tillage, contour tilling, terracing, and other soil-conserving BMPs are becoming increasingly popular in the SHP, slowing sedimentation rates in playas in some playas (Bunn, 1997; L.M. Smith, oral commun., 2005). Flood irrigation, and the return of tailwater into playas, has been replaced in many locations by center-pivot irrigation, which results in less erosion of cropland soils. Negative consequences of this trend are that it is expensive to pump groundwater and the Ogallala aquifer is being over-mined (Luckey and others, 1988); however, to some extent these issues are now encouraging more dryland farming, which usually leads to less erosion than irrigated farming. The Conservation Reserve Program (CRP) also has helped to slow the rate of sedimentation in some 
playas, and, in 1995, most SHP farmers re-enrolled in the CRP (D.A. Haukos, oral commun., 2005); whether or not economics will allow that trend to continue remains unknown (Luo and others, 1997).

A playa basin affected by sedimentation, may no longer hold much, if any, water. Playa function also may be disrupted by tilling or modification (i.e., pits dug in the basin to decrease watersurface area and reduce evaporation), which can damage the clay layer. Furthermore, modified playas may have limited value to wildlife, as the modifications generally destroy the littoral zone. Although some excavation work has taken place in the Rainwater Basin (L. Wetterberg and J. Jasmer. oral commun., 2005), there is no tested protocol for salvaging sediment-filled playas, nor is there a protocol for restoring the clay layer of a modified playa. Either type of basin damage warrants serious consideration and possible restoration before funding and human resources are applied to buffer protection for those basins.

\section{Nutrients}

Nitrogen $(\mathrm{N})$ and phosphorus $(\mathrm{P})$ entering wetlands is a significant problem throughout the world. The primary source of excess nutrients is agricultural runoff, but sewage wastewater, lawn/golf course fertilizers, and other sources also contribute to the problem (Sharpley and others, 2001). Much of the $\mathrm{N}$ that enters terrestrial systems is fixed by soil bacteria, taken up by plants, or volatilizes (enters a gaseous state) before it reaches wetlands; however, the remaining $\mathrm{N}$ can contribute to ammonia accumulations in sediments, which, in turn, can generate anoxic conditions (Irwin and others, 1996). Factors affecting the extent and rate of nutrient transport include intensity and duration of precipitation (as well as irrigation runoff or return of irrigation tailwater to playas), temperature, antecedent soil moisture, percent cover of residual vegetation, soil type, and slope.

An overabundance of $\mathrm{N}$ and $\mathrm{P}$ in wetlands promotes excessive primary production, which leads to significant amounts of decomposition and associated anoxia (Sharpley and others, 2001). Algal blooms and the eventual anoxia can significantly alter chemical and community composition within a wetland (Irwin and others, 1996; Rocke and Samuel, 1999). Moreover, anoxic conditions, combined with increases in water temperature, $\mathrm{pH}$, and salinity, may be important factors in promoting outbreaks of botulism (Clostridium botulinum). These relationships, however, are complex and require additional study (Nelson and others, 1983a; Irwin and others, 1996; Rocke and Samuel, 1999; Wobeser, 1999).

In simplified terms, $\mathrm{N}$ and $\mathrm{P}$ in runoff occur in dissolved (water soluble) or undissolved (bound to sediment or debris) forms. Both dissolved and undissolved forms of $\mathrm{N}$ are easily transported over terrestrial systems to wetlands (Magette and others, 1989). Most P in agricultural systems occurs in the undissolved form, which binds more readily to sediments and plant residues than N. Even at relatively high levels, undissolved P is unavailable to plants (Miyasaka and Habte, 2001). However, when undissolved $P$ is transported into wetlands, it may persist in sediments for decades (Sharpley and others, 2001), and it remains unclear how it may eventually affect ecological processes of wetlands (see Rocke and Samuel, 1999).

Primary sources of excess nutrients in playas of the PLR include manures and synthetic fertilizers applied to agricultural lands. In localized areas, playas are heavily impacted by feedlot runoff and/or sludges from wastewater and feedlots dumped directly into playas. Playas impacted by the level of nutrients associated with feedlots are characterized by significantly reduced biodiversity, particularly of invertebrates (Irwin and others, 1996).

Most excess $\mathrm{P}$ in agricultural systems occurs in the undissolved form, bound to substrates that may be transported if the substrates become mobilized. Thus, even though fine-textured soils are not as susceptible to erosion as coarser soils, more undissolved $\mathrm{P}$ is likely to occur in runoff of finetextured soils because their greater particle density provides more surface area to which $\mathrm{P}$ may bind (Abu-Zreig and others, 2003). Unlike undissolved P, dissolved P is easily transported in water 
(Sharpley and others, 2001), which means that if water runoff containing dissolved P passes through a buffer, it is likely to enter the wetland.

Managing nutrients is a two-fold process: (1) diminishing their input and (2) precluding their mobility (Sharpley and others, 2001). Diminishing input includes not only fine-tuning applications of fertilizers and preventing feedlot runoff, but also refining the dietary intake of nutrients by livestock. Many livestock producers apply manure to croplands for meeting the $\mathrm{N}$ requirements of crops, but due to typical manure ratios of $\mathrm{N}: \mathrm{P}$, adequate inputs of $\mathrm{N}$ can result in excessive inputs of $\mathrm{P}$. Livestock producers often provide their animals with more nutrients than needed, including metallic elements, which are subsequently excreted and potentially transported to wetlands.

Methods of nutrient application and soil preparation also affect the potential plant uptake and eventual transport of nutrients. For example, King (1981) found that grass uptake of N was greater where $\mathrm{N}$ was surface-applied than where it was disked into the soil. Conservation tillage, on the other hand, will help control nutrient transport by reducing erosion (thus transport of undissolved nutrients; see Sprague and Triplett, 1986). However, even where vegetation cover or surface roughness adequately precludes surface runoff of $\mathrm{P}$ - or $\mathrm{N}$-containing sediments, dissolved $\mathrm{P}$ and $\mathrm{N}$ may still runoff in subsurface strata. Significant amounts of dissolved $\mathrm{P}$ in subsurface regions may be bound up through fixation with subsoils deficient in $\mathrm{P}$, but soil conditions characterized by low $\mathrm{pH}$, low percent organic matter, sandy texture, and/or significant soil porosity can retard or result in $\mathrm{P}$ bypassing this process (Sharpley and others, 2001). In addition, where soils are not P-deficient, dissolved P may leach through subsurface strata and eventually enter nearby wetlands; the extent to which this could happen in playa watersheds where the clay-lined basins of playas may protect them from subsurface leaching is unknown.

Other BMPs for reducing nutrient transport include avoiding application of nutrient-rich manures or fertilizers within playa watersheds when intense, prolonged rain or other significant water runoff is predicted in the immediate future. Perhaps one of the most feasible BMPs for reducing nutrient runoff would be to establish a no-application zone around playas and their buffers. Local groups of farmers and ranchers also may be encouraged to establish manure banks for transporting manures from P-rich operations to operations deficient in P (Sharpley, 2001).

\section{Pesticides and Heavy Metals}

Pesticides vary tremendously in their degradation rates and toxicity levels. In general, pesticides can travel long distances on contaminated soil particles carried by wind or in rainfall, and aerial applications of pesticides generally drift beyond target zones. Of the pesticides known to occur in playas, herbicides are perhaps the greatest threat because they are broadcast widely and frequently across regions and crop types. Herbicides have been detected in all (Irwin and others, 1996) or nearly all (Thurman and others, 2000) playas tested in the SHP, even in watersheds considered relatively undisturbed (Irwin and others, 1996). Typically, reductions in herbicide runoff are due primarily to sediment settling (adsorbed herbicides) and water infiltration (dissolved herbicides) (Dillaha and others, 1986; Arora and others, 1996; Misra and others, 1996; Patty and others, 1997; Tingle and others, 1998; Seybold and others, 2001). Overall, infiltration tends to be greater in coarser soils (due to greater porosity) than finer soils.

Heavy metals were found in most SHP playas evaluated by Irwin and others (1996). Of the metalloids known to harm wildlife, arsenic was among the most-widely distributed, possibly because arsenic can be transported via contaminated, wind-borne soil particles. Herbicides containing arsenic, especially those frequently associated with cotton production, are likely sources of elevated arsenic levels in playa sediments. Copper also occurs at relatively high levels in playas, due, in part, to feedlot runoff (excess of dietary intake and subsequent excretion) and runoff from copper-based pesticides. Copper can be transported into wetlands and accumulate to levels that are toxic to aquatic plants and animals (Wu and others, 2003). Boron, chromium, iron, manganese, selenium, vanadium, 
and zinc are also of concern in many playas. Significant sources of most of these elements include petroleum-extraction activities (e.g., dumping of oil brines directly into playas), urban sewage (sometimes dumped directly into playas), and feedlots, and generally they are more localized than the other pollutants described above.

Soil infiltration is a primary means of reducing dissolved contaminants from runoff. In a study by Seybold and others (2001), 53-73\% of the herbicide (atrazine and metolachlor) in runoff was removed by VFSs, primarily due to soil adsorption and infiltration of water containing dissolved herbicides. Once contaminants are in the soil, plant uptake or microbial action and other decay processes can sequester and neutralize the dissolved nutrients, herbicides, and other pesticides.

A number of BMPs may help reduce the potential for pesticide and heavy metal transport within watersheds. Based on a review of research from 1970-1990, Baker and others (1995) found that conservation tillage (no-till) alone can reduce herbicide runoff by an average of $60 \%$. This may be due to reduced soil erosion under no-till regimes, which, in turn, would reduce transport of herbicide-carrying sediments and plant residues. However, Sauer and Daniel (1987), Mickelson and others (2001), and others, have found that herbicide runoff is greater from no-till plots. To some extent, this difference may be due to measuring dissolved versus undissolved herbicide. Mickelson and others (2001) found 2-10 times more herbicides in sediments (i.e., bound to the sediments) than in water, but $>95 \%$ of the herbicide lost to runoff was in the dissolved form (i.e., in water, possibly explaining why Baker and others [1995] concluded that no-till methods reduce herbicide runoff). Because the herbicides used in Mickelson and others (2001) study had low adsorption capabilities, they were easily transported by water. Mickelson and others (2001) also detected significantly greater concentrations of herbicide runoff from plots that were sprayed with herbicide after disking than from those where herbicides were applied before disking.

The effects of no-till versus conventional till on herbicide concentrations in runoff may be a function of experimental plot size, duration/intensity of rainfall, time elapsed between application and rainfall (or irrigation), residual herbicides remaining on soil and plant surfaces prior to application, and/or adsorption capabilities of herbicides. It also seems that some of the confusion stems from the comparability of response variables measured (e.g., total herbicide loss versus herbicide concentrations in water or sediment).

BMPs that may minimize herbicide transport include conservation tillage, contour tillage, and mulching, depending on local conditions and herbicides used. Where soil erosion is less problematic but herbicides used are of the low-adsorption type and/or applications are heavy or frequent, mulching or disking after herbicide applications may be helpful. Where soils are coarse, BMPs that maximize soil retention and water infiltration may be necessary to minimize herbicide runoff. Buffers alone are limited in their abilities to protect playas from contaminants carried in wind or rainfall. BMPs to reduce aerial transport include no-spray zones around wetlands and buffers and delaying application of herbicides when rain is predicted. Patty and others (1997) found an inverse relationship between the amount of herbicide residues in runoff and time that elapsed between herbicide application and first rainfall.

The impacts of herbicides on living organisms still requires significant research, but there is mounting evidence that their effects may be long-term and have profound implications for wildlife populations. For example, scientists are finding that herbicides may be a major factor in the alarming population declines among amphibians; Hayes and others (2002) suspect that herbicides are causing demasculinization among male frogs. Similar problems have been detected in other taxa (especially aquatic wildlife). The effects on birds remain poorly understood.

Historical accounts of wildlife mortality events directly attributable to insecticides in the PLR are fairly infrequent and generally limited to localized areas (e.g., White and others, 1982; Flickenger and others, 1991). In samples of sediments, invertebrates, and aquatic plants taken from playas across the PLR, Irwin and others (1996) infrequently found detectable levels of insecticides; the few cases in 
which there were detectable levels of insecticides entailed organochlorines (DDE, a by-product of DDT), which are known to persist in the environment.

Most of the newer, organophosphate (OP) insecticides are short-lived and do not appear to persist in the environment, but the short-term toxicities of some OPs can be significant. White and others (1982) and Flickenger and others (1991) reported large, insecticide-caused mortality events (1,600 and 200 waterfowl, respectively) that occurred at single playas two days after OPs had been applied to within 100 and $15 \mathrm{~m}$, respectively, of the playas. The event reported by White and others (1982) resulted from aerial spraying of parathion and methyl parathion to control an outbreak of greenbug (Schizaphis graminum) in fields of wheat. The incident reported by Flickenger and others (1991) resulted from parathion alone, which had been sprayed on a wheat field to control Russian wheat aphids (Diuraphis noxia). In each case, the birds had foraged on treated wheat plants when the insecticides were still very toxic. Practices that could diminish wildlife exposure to insecticides include establishing no-spray zones around playas, hazing wildlife in treatment areas during, and for some time after, treatment, and avoiding the use of highly toxic compounds, such as parathion, near playas and buffers. At least for ducks, malathion has been found to be the least toxic (albeit more expensive) OP for use against greenbug infestations on wheat in the Texas panhandle (White and others, 1982).

\section{Potential Buffer Effects on Overland Water Flow}

To date, very little research has evaluated the ways in which buffers or VFSs affect the hydrologies of their associated wetlands (but see van der Kamp and others, 1999; Abu-Zreig and others, 2004), an issue of significant concern in semi-arid regions such as the PLR. Because water is the primary agent responsible for mobilizing sediments, nutrients, and pesticides in most watersheds, the primary means of keeping mobilized sediments and contaminants out of playas are to reduce the velocity at which runoff water flows and to increase soil infiltration of contaminated water.

However, it is the balance between runoff and infiltration that largely determines whether or not water eventually enters a given watershed basin (van der Kamp and others, 1999; Abu-Zreig and others, 2004). Van der Kamp and others (1999) found that small, isolated wetlands in central Saskatchewan completely dried out after $1 / 3$ of their watershed had been converted from dryland farming to perennial, unmanaged cover of smooth brome brome (Bromus inermis) and alfalfa (Medicago sativa), due, in part, to increased infiltration.

Runoff velocity is largely a factor of runoff volume, slope, surface roughness, and obstructive factors on the slope. As runoff velocity diminishes, solids begin to settle out of the water. Solids include not only sediments, but also plant residues and sediment- or residue-bound pollutants. Heavier and larger particles (e.g., gravel and sand) will drop out first, but as velocity diminishes and slow-down or ponding time increases, silt particles will drop out (Wilson, 1967). Clay particles are among the last to drop out; even after water has filtered through a wide buffer, it may still contain clay particles (Van Dijk and others, 1996). (This supports the theory that a limited, 'endemic' form of erosion may have been what led to the formation and maintenance of clay basins in playas.)

Infiltration rates are affected by many climatic, biotic, and abiotic factors, including but not limited to the following.

- Rainfall duration and intensity. Long, gentle rainfalls usually result in more infiltration than short, intense rainfall events.

- Antecedent soil-moisture conditions. Infiltration is greater in dry than saturated soils. Lin and others (1998), who reported effects of soil moisture on infiltration rates in vertic (clay) soils of various regions in Texas, found that dry soils are generally more porous than wet soils. 
- Soil structure and texture. Infiltration rates tend to be greater in coarse-textured than in finer soils and where macropores are prevalent. Lin and others (1998) found that porous soils allow greater infiltration than tighter soils.

- Slope and evenness of surface flow. More infiltration occurs with even surface flows on gentle rather than steep slopes.

- Stem density. More water is retained in denser stands. Grass hedges, buffers characterized by high stem densities, can effectively block runoff (Kemper and others, 1992; Eghball and others, 2000).

- Grass life history. The degree to which grass life histories influence soil-water relationships and infiltration rates in playa watersheds is not known. At higher elevations in West Virginia, cool-season grasses $\left(\mathrm{C}_{3}\right)$ depleted soil-water more than warm-season grasses $\left(\mathrm{C}_{4}\right)$, especially in late spring and late summer when cooler temperatures favored growth of $\mathrm{C}_{3}$ grasses (Feldhake and Boyer, 1995). Although most rainfall in the PLR occurs from May to September, it tends to peak in late spring (May) and again in late summer (September), when conditions favor the growth of cool-season grasses. If coolseason grasses were included in playa buffers in the PLR, it's not clear whether they would deplete soil-water more than warm-season grasses.

- Grass structure, growth form, and native status. Two playa-system experts of the SHP believe that grass life history is not as important to water uptake as grass structure, growth form, and native status, and that natives in the semi-arid PLR would likely be more efficient water users (D.A. Haukos and D. Gitz, oral commun., 2005). In the southwestern portion of Nebraska, species of mid to tall heights, non-natives, and/or cool-season grasses planted during earlier phases of the CRP program are thought to preclude water from flowing into playas surrounded by CRP fields. This was based on observations that wetlands in watersheds of winter wheat or disked fields held water after 2-3" rain events but playas in CRP fields did not (T. J. Walker, written commun. to R. Walters, 2004). Van Dijk and others (1996) found that, for a given filter width, older grass retained more water than younger grass, due primarily to roughness coefficients that increased with increasing stem density and litter residue typical in stands of older grasses.

By definition, buffers and other BMPs designed to promote infiltration diminish overland water flow to playas. Buffer width, an element of buffer design, clearly influences the volume of water that infiltrates. However, the buffer width required to reduce runoff depends on all the factors listed above, in addition to local climate, soils, and vegetation. For example, during controlled experimental work, Abu-Zreig and others (2004) found that $46 \%$ of runoff (simulated rainfall) in experimental field plots was retained in 10-m wide filters, whereas Tingle and others (1998) report that VFSs only $0.5 \mathrm{~m}$ wide reduced the cumulative water runoff by $46 \%$. It is not clear how slope, plot size, vegetation species, antecedent soil-moisture, and other factors affected these results. In 'real-world' watersheds, additional important factors include historical land-use and management practices.

BMPs that reduce runoff velocity via semipermeable obstructions include no-till soil preparation (the vegetative residue serving as a filter), tilling crop rows along landscape contours instead of parallel with the slope (the furrows serving as tiny 'check dams'), and planting buffers and VFSs. Practices that alter soil structure can also promote or diminish infiltration. Soil compaction will diminish or even preclude infiltration, whereas tilling and disking generally promotes infiltration. However, a study conducted by Detenbeck and others (2002) in the prairie pothole region exemplifies the complexities of how soil structure can affect runoff and infiltration. They found that less runoff 
entered potholes where the land was currently enrolled in the Conservation Reserve Program (CRP) or a similar revegetation program called REST than in currently tilled watersheds, whether or not the potholes were buffered. This illustrates the extent to which perennial vegetation can diminish runoff by promoting infiltration. However, Detenbeck and others (2002) also found that water levels in potholes surrounded by native prairie were higher than those surrounded by REST uplands. In this case, they attributed the difference to effects of tillage history on infiltration; less runoff was able to penetrate the undisturbed prairie soils than the historically tilled REST soils.

Overall, it is clear that the balance between runoff and infiltration must be considered carefully when planning buffers. In some playa watersheds, runoff of dissolved contaminants may be high enough to warrant BMPs that promote significant infiltration. However, not only should contaminant levels determine infiltration need, the probability that high levels of contaminated runoff will continue to impact a given playa should also be factored in, if possible. Where high levels of dissolved contaminants may be temporary, the long-term effects of diminishing runoff to the playa by promoting infiltration could be more damaging than short-term influxes of contaminants. To some extent, the half-life, persistence, and relative toxicity of the contaminants involved will also need consideration before implementing infiltration-promoting BMPs.

\section{Buffers: Design and Effectiveness, Models, and Management}

The large body of literature on design and effectiveness of wetland buffers and VFSs primarily describes short-term studies in highly controlled situations and focuses on preventing erosion and sedimentation, although the number of publications on buffer-trapping effectiveness for nutrients, pesticides, pathogens, and heavy metals is increasing. Most studies were conducted in field plots or trays that were subjected to simulated slopes and rainfall applied in even sheet flows across the plots. Of the few field-plot or watershed studies conducted in the U.S., only one was conducted in an arid region (Arizona; Wilson, 1967), whereas the others were conducted in regions that receive more moisture than the playa region, including the mid-Atlantic coastal plains and uplands, central and northern regions of the Midwest, the Southeast, and logging regions of the Pacific Northwest. Monitoring of the effectiveness of recently ( $<5$ years) buffered playas in western Kansas (G. Jasmer, oral commun., 2005) and the Rainwater Basin (L. Wetterberg, oral commun., 2005), is ongoing but not yet published. To date, no work has evaluated sediment-trapping effectiveness (STE) of buffers using native vegetation in arid or semi-arid regions (Abu-Zreig and others, 2004), and no buffer studies have been conducted in the PLR (D.A. Haukos and D. Gitz, oral commun., 2005).

The examination of 'real-world' buffer situations is crucial, as inadequacies and unanticipated effects may be revealed. For example, Dillaha and others (1989b) found that 'real world' VFSs at farms in the mid-Atlantic region were not as effective as experimental VFSs, particularly at higher runoff volumes and on steeper slopes. The buffers had to absorb runoff from much larger areas than the areas in experimental plots, and the runoff tended to concentrate in a few natural drainageways that cut narrow pathways across buffers (thus rendering them ineffective) rather than flowing in even sheets throughout the buffers. Of the 'real-world' buffer studies, most have examined the value of woody (or a combination of woody and herbaceous) vegetation for protecting riparian systems; almost no studies have explicitly addressed buffers, woody or herbaceous, for protecting isolated wetlands.

Currently, buffer recommendations are primarily based on expert opinion, particularly as it relates to reductions of nutrients and pesticides (Dosskey, 2001), and professional interpretations of the greenhouse and field-plot experiments reported in the literature. Economic feasibility and political acceptability has also been a major driving factor in buffer recommendations (Castelle and others, 1994). The NRCS provides detailed standards regarding filter strips for each county in the PLR (Natural Resource Conservation Service, 2005), however, the effectiveness of these standards has not been evaluated. These buffer recommendations are likely predicated on landowner tolerances for 
losing production land, and on interpretation of experimental data not validated in real-world watersheds. There is concern that current NRCS buffer recommendations are based on erosion curves that are not accurate enough (Dillaha, 1989; L.M. Smith, oral commun., 2005).

Because real-world data are lacking, potential buffer designs implied by the studies described below should be regarded as preliminary rather than definitive recommendations. The implementation of herbaceous buffers for protecting real-world playas should be treated as part of a broad-scale experiment, during which adaptive buffer management may be necessary and effectiveness monitoring should be conducted, analyzed, and published (D.A. Haukos, oral commun., 2005). Provisions in current funding programs for buffers now require monitoring for effectiveness to some extent (A.W. Allen, oral commun., 2005); establishing buffers in such a way that they ensure comparable replicates and controls and standardized measures of effectiveness would elevate the value of monitoring data enormously. If pre-treatment data can be collected, the presumed effects of buffers would be more credible.

\section{Buffer Widths and Other Design Considerations}

For this synthesis, we focused on a variety of authors who have published numerous papers on buffer or VFS design and effectiveness, and on existing bibliographies and literature reviews. Appendix 2 illustrates the broad spectrum of research approaches used and buffer design and runoff issues addressed. The ensuing discussions of these buffer design and effectiveness studies may facilitate buffer design for varying conditions in the PLR, although we recognize that some scenarios and conditions in the PLR differ substantially from those of the reported studies. Thus, a general discussion of average or typical buffer effectiveness for a range of widths and other design considerations for a given runoff problem, soil-texture, land use, management regime, and other factors may be instructive.

Effective buffer widths reported in the literature range from $<1 \mathrm{~m}$ (generally for grass hedges; Kemper and others, 1992; Eghball and others, 2000) to $300 \mathrm{~m}$ (Wilson, 1967; Wong and McCuen, 1982), with wider buffers generally implemented where sediment loads, contaminant levels, and runoff flows are extreme. Castelle and others (1994) provide a useful line graph that indicates the range of buffer widths in the literature for addressing specific runoff problems. Generally, reducing most sediments requires buffers of 10-60 $\mathrm{m}$ (although the issue of clay particles is not addressed separately; see discussion below); the same graph indicates that buffers of 10-90 $\mathrm{m}$ are generally adequate for reducing nutrients. Although the graph does not include buffers for reducing pesticides or metals, required widths are generally similar to those reported for nutrients (see discussion on particle size below). Because most research on grass buffers has entailed tall- or medium-height grasses, it is not clear how the use of native short- and medium-height grasses in playa buffers may affect buffer widths necessary in the PLR.

As mentioned earlier, sediment-retention efficiency for a given buffer width increases with increasing soil-particle size (Wilson, 1967; Dosskey and others, 1997), and this relationship is nonlinear (Wilson, 1967; Wong and McCuen, 1982; and Abu-Zreig, 2001). For example, Wong and McCuen (1982) found that if the criterion of percent sediment removal on a $2 \%$ slope was increased from 90 to $95 \%$, the buffer width had to be doubled from 30.5 to $61 \mathrm{~m}$. Van Dijk and others (1996) found that most larger particles dropped out within the first $0.6 \mathrm{~m}$ of grass strips, but particles $<125$ microns (clay particles) were able to pass through, regardless of strip width. In southern Arizona, Wilson (1967) observed that the majority of sediments dropped out in the first $15.4 \mathrm{~m}$, but the maximum STE was at $3.5 \mathrm{~m}$ for sand, $15.4 \mathrm{~m}$ for silt, and $91.5 \mathrm{~m}$ for clay particles. Therefore, where soils in the PLR are medium- to coarse-textured, buffer widths may not need to be as wide as they would need to be where soils are fine-textured. However, this also depends on land-use, slope, and other factors. Most croplands of the PLR occur in fine-textured soils while rangelands tend to dominate medium-textured soils (Nelson and others, 1983a), and because erosion is typically much 
greater in croplands than in rangelands (Luo and others, 1997), buffers may need to be wider in croplands, despite the presence of fine-textured soils.

Where nutrient runoff is significant (especially dissolved nutrients), or where concentrations of dissolved agrochemicals are high, buffer widths will also need to increase accordingly, as the main mechanism for removal of these contaminants is infiltration, which increases with filter width. Undissolved pollutants will fall out with sediments to which they are bound; thus, if buffer width is adequate for trapping most sediments, it will be reasonably adequate for trapping most sedimentbound contaminants. However, the relationships between nutrient/herbicide reductions and filter width are complicated significantly by soil texture and porosity (i.e., adsorption and infiltration capacity), slope and rainfall amount (extent of dilution, amount of water escaping infiltration; Schmitt and others, 1999), antecedent soil-moisture, and other factors. Numerous authors report that previously bound nutrients may eventually dissolve or mineralize and be released into future runoff. Thus, results of studies evaluating buffer effectiveness for removing pollutants are far more varied than those of sediment-trapping studies.

Where feedlots threaten playas, a single buffer may not be enough, and some authors suggest a series of buffers that trap nutrients repeatedly as runoff travels downslope. Grass hedges or very dense VFSs right at the feedlot edge may be useful for lightening the burdens of contaminants moving downslope of the hedges while still allowing precipitation gathered from the remainder of the watershed to reach the playa.

Numerous experimental studies also indicate that buffer widths may reach a threshold beyond which they become relatively ineffective. In particular, STEs of buffers generally exhibit nonlinear trends, with the greatest benefits imparted in the first few meters of buffer encountered by runoff (e.g., Wong and McCuen, 1982; Abu-Zreig, 2001). Whether long-term accumulations of sediments may affect these trends remains uncertain. In any case, buffers that are wider than necessary are likely to result in more infiltration (Detenbeck and others, 2002; Abu-Zreig and others, 2004), which could be a problem in a semi-arid region like the PLR. In addition, landowner resistance may increase with increasing buffer width, as more buffer area may encompass otherwise-productive land.

Tillage method also significantly impacts effectiveness of a given buffer width. Conventional tillage generally requires wider buffers than conservation tillage, although the results of studies evaluating this relationship are conflicting (e.g., Shaw and Webster, 1994; Sprague and Triplett, 1996; Bunn, 1997; Barfield and others, 1998; Tingle and others, 1998; Mickelson, 2001). To some extent, conflicting reports may result from differences in runoff problems being measured (sediment versus pollutants), crop type, ratio of dissolved to undissolved contaminants reported in runoff, rainfall intensity, slope, soil type, percent crop residue, and extent of residue mulching, among other factors. In the last 20 years, a number of BMPs have been implemented in the PLR to help reduce erosion and protect wetlands, including contour tilling, terracing, and other BMPs (L.M. Smith, oral commun., 2005). However, significant soil disturbance continues, and croplands under conventional tillage regimes will likely require wider buffers to handle both incoming sediments and, in some cases, significant runoff of plant residue. One study revealed the inadequacy of 0.5- and 1-m VFSs buffering conventionally tilled cotton fields (Murphy and Shaw, 1997), consistent with studies that promote buffer widths of at least $10-15 \mathrm{~m}$ for most sediment runoff scenarios.

Large, directed flows of runoff can threaten the integrity of buffers placed at wetland edges or field margins. To deal with this problem, small areas of a given watershed that are responsible for predictable and disproportionately large amounts of runoff could be targeted for buffer placement to, in effect, 'buffer the buffer' from inundation (Qui, 2003). This approach may be useful for protecting playas without asking farmers to give up significantly more production land by widening buffers considerably, as it is possible that concentrated runoff areas are also troublesome in terms of crop production.

The U.S. Fish and Wildlife Service Partners for Wildlife Program has promoted a buffer program for playas in the SHP for several years (D.A. Haukos, oral commun., 2005). In this program, 
a buffer width of $\sim 33 \mathrm{~m}$ planted with a diverse mix of native shortgrasses and mixed grasses is recommended as a starting point. However, where focused runoff occurs (channels, drainageways, abrupt changes in landscape contour), buffers may need to be as wide as 50-70 m, and where slopes exceed 4\%, Haukos recommends buffer widths according to the amount of land a farmer is willing to give over to buffers. Smith (2003) indicated that buffer widths for playas (30-90 m) have been based on 'best judgment.'

\section{Vegetative Structure and Species Potentially Useful for Playa Buffers}

Several characteristics are considered favorable for playa buffer grasses: native status, short to medium heights, an ability to germinate in and tolerate the PLR's soil and climate conditions, the ability to grow up through accumulating sediments, and local commercial availability of diverse, native seed mixes (D.A. Haukos, oral commun., 2005). Native forage species typically meet nutritional needs of wildlife better than non-natives (including crops). The habitat value of playas may be greatest where floral diversity is greatest (Bolen and others, 1989). Buffers in playa systems may not necessarily require the tall, stiff grasses that resist high water velocity and deep runoff common to other regions; in the PLR, short to mixed grasses should suffice because slopes are gentler (D.A. Haukos, oral commun., 2005), although taller, stiffer grasses may be necessary where runoff is directed. No research has yet been conducted on the effectiveness of shortgrasses in buffer applications (L.M. Smith, oral commun., 2005). Although shortgrasses and mixed grasses certainly 'buffered' playas historically, historical scenarios did not include inundations of sediments due to chronic overgrazing and soil disturbed by agricultural activities. Grasses with evenly distributed stems filter runoff more efficiently. Dillaha and others (1986) indicated that removal of trees, stumps, shrubs, and other materials that disrupt the evenness and density of grass in a VFS is recommended, as they impair sheetflow and buffer effectiveness.

A diversity of shortgrass to mid-height grass species is recommended by the USFWS Partners for Wildlife Program, including blue gramma (Bouteloua gracilis), sideoats gramma (Bouteloua cutipendula), and plains bristlegrass (Setaria verticillata) (D.A. Haukos, oral commun., 2005). In general, nutrient uptake will require actively growing, leafy plants (i.e., not dormant). Western wheatgrass (Agropyron smithii) may be a useful component of playa buffers; it is valued as forage for livestock and is expanding its range southward (D.A. Haukos, oral commun., 2005). Vine mesquite (Panicum obtusum), a sod-forming, mid-height grass, is also a useful perennial for buffers because its stolons are significant and can grow up to 15 feet in a single growing season, and it naturally grows around playa edges. Western ironweed (Veronica baldwinii) is a common prairie forb known to concentrate $\mathrm{P}$, thus it may be useful where $\mathrm{P}$ build-ups are significant (L. Wetterberg, oral commun., 2005; see http://www.lib.ksu.edu/wildflower/ ironweed.html). Cattle, however, will avoid ironweed, thus it tends to increase in overgrazed pastures. Vine mesquite may be useful for nutrient uptake in PLR buffers because it has long wide leaves, needs minimal precipitation, grows well in clayey soils, livestock will select it, and it withstands heavy grazing (Stubbendiek and others, 1981). Switchgrass (Panicum virgatum) and indiangrass (Sorghastrum spp.) are not particularly suited to the arid conditions and tight clay soils of the SHP (D.A. Haukos, oral commun., 2005; R.A. Gleason, oral commun., 2005), but there are scenarios where switchgrass may be useful. Runoff on longer slopes or concentrated in channels or drainageways may submerge buffer grass or cause it to bend (Van Dijk and others, 1996), warranting use of tall, stiff grasses, such as switchgrass or big bluestem (Andropogon gerardii) (Kemper and others, 1992).

A number of authors and experts consulted agree that there are certain species that should not be used in playa buffers because of non-native status, invasive tendencies, water-intensive physiologies, or inabilities to tolerate PLR soils. Species mentioned specifically include smooth brome, lovegrass (Eragrostis cilianensis), reed canarygrass (Phalaris arundinace) (L. Wetterberg, oral commun., 2005), and other Old World Poacea spp. (M.G. Dosskey, D.A. Haukos, L.M. Smith, 
and L. Wetterberg, oral commun., 2005). Smooth brome is an exotic, cool-season invasive with shallow root systems that may become dislodged during high-velocity runoff (M.G. Dosskey, oral commun., 2005). Lovegrass will outcompete native species (D.A. Haukos, oral commun., 2005). Reed canarygrass can form monocultures and it is an intensive water user (L. Wetterberg, oral commun., 2005). Barnyard grass is an invasive warm-season grass that can grow 0.3-1.6 $\mathrm{m}$ in height (Whitson and others, 1996) and may be capable of shading out native shortgrasses; however, this species is frequently described as an important food resource (seeds) for waterfowl overwintering in playas (e.g., Haukos and Smith, 1994).

\section{Models for Predicting or Evaluating Buffer Effectiveness}

A number of predictive buffer models have been developed and are undergoing validation and adjustments using field data. NRCS buffer recommendations are based on such models (M.G. Dosskey, oral commun., 2005). Because of concern about the accuracy of these models (L.M. Smith, oral commun., 2005), it may be prudent for land managers to seek more in-depth modeling assistance for designing buffers within a given set of playa-specific scenarios. Some of the available models include CREAMS (Chemical Runoff and Erosion from Agricultural Management Systems; Knisel, 1980), GLEAMS (Groundwater Loading Effects of Agricultural Management Systems; Leonard and others, 1987), GRAPH (Lee and others, 1989), REMM (Riparian Ecosystem Management Model; Inamdar and others, 2000), and VFSMOD (Vegetative Filter Strip Model; Abu-Zreig, 2001). GLEAMS deals with ground-water pollution, which may have some useful applications for determining water lost in buffers. REMM (Inamdar and others, 2000), a complicated model that incorporates evapotranspiration losses and is sensitive to slight variations in data input (M. Dosskey, oral commun., 2005), has been used by its developers and a few other people. A helpful review and tabulation of models available as of 1990 is available (Dillaha, 1990).

\section{Buffer Management}

Little has been published on the effects and effectiveness of different buffer-management regimes (D.A. Haukos, oral commun., 2005), but some level of management will be required (Dillaha and others, 1989a; Castelle and others, 1994; Dewald and others, 1996). Buffers can become overburdened with sediments and/or plant materials that have accumulated high levels of nutrients. Buffer vegetation also may lose vigor, thus diminishing its wildlife value, or be overcome with weeds that crowd native plants and croplands. Constant monitoring of buffer integrity is necessary, and, when breached by directed or relatively deep flows (Dillaha and others, 1986) or due to activities of fossorial animals (Kemper and others, 1992), buffers require immediate repair and reseeding. Ultimately, buffers are not recommended for use where fossorial animal activity is significant, because frequent and costly repairs may preclude vegetation from attaining the maturity level required for buffer effectiveness.

Several management tools are available for use in buffers.

- Disking and reseeding. If sediment loads become too great for buffers to remain effective, they may need disking (and reseeding) (NRCS, 2005). In severe cases, grading or even excavation may be required (Dosskey and others, 1997). Because runoff rarely occurs in even sheetflows throughout a buffer, certain patches may hold larger sediment loads, in which case only those patches may need maintenance.

- Burning or disking followed by replanting. These techniques may be useful for promoting new growth and vigor in existing buffer grasses, restoring grasses after damage, eliminating invasive or exotic species, or preparing a seedbed for new grasses. In at least one study, infiltration was greater in older grass buffers (Van Dijk and others, 1996), 
although whether this would apply to native shortgrasses in the semi-arid PLR is unknown. Under favorable conditions, new plantings of native grasses in the SHP require 3-4 years of growth before they can sustain any grazing or other form of vegetationreducing management (A.W. Allen, oral commun., 2005). The wildlife food value of younger, more vigorous vegetation tends to be greater than that of older vegetation (Dillaha and others, 1986).

- Haying and short-term grazing. Where nutrient runoff is excessive in a given playa watershed, nutrient accumulation in plant materials may require removal through haying (mowing would leave the nutrients in place) or short-term grazing. Short-term grazing that does not result in damage to the buffer itself can be a useful management tool for reducing dense cover, weeds, or reinvigorating plant growth. Grazing can also affect plant species composition; grazing explained $65 \%$ of the variation in occurrences of buffalograss in a playa watershed (Guthery and Stormer, 1984). In shortgrass buffers, there may be little need to reduce accumulations of litter (A.W. Allen, oral commun., 2005).

- Burning. Little is known about potentially short-term effects of burning buffer vegetation as a management tool. Certainly, if all of a buffer is burned at once, a subsequent rainfall could result in significant runoff of sediment or pollutants into the buffered playa. However, D.A. Haukos (oral commun., 2005) indicated that burning is a common and acceptable practice for vegetation management in the Texas SHP, and he did not feel it should be overlooked as an option for managing playa buffers, at least in that region. Haukos believes, however, that if buffer vegetation is burned, it should be done on about a 3 -year rotational basis, burning only a portion of the buffer in any one year. Ultimately, research is needed to determine the effects of burning buffer vegetation.

- Applying fertilizers and herbicides. NRCS (2005) Conservation Practice Standards (which vary by region) also generally indicate that fertilizing buffers and weed control may be necessary. However, any use of fertilizers or herbicides in buffers, especially those immediately adjacent to playas, will require careful evaluation to avoid increasing contaminant burdens in playas. Where nutrient runoff is already a problem, fertilizers might not be necessary after buffers become established, depending on the species of nutrients (plant-available compounds, ratios of $\mathrm{N}: \mathrm{P}$, etc.) reaching the buffer. In most cases, mowing, haying, or grazing may be all that is required to control weeds.

The time of year that may be best for haying, mowing, grazing, or burning of buffer vegetation is late summer/early fall, generally early to mid-September in the SHP (D.A. Haukos, oral commun., 2005) and somewhat earlier farther north in the PLR (Bryan and Best, 1991). By early fall, severe runoff-producing summer storms begin to subside and temperatures are warm enough to allow some buffer regrowth. The U.S. Fish and Wildlife Service Partners for Wildlife Program allows grazing from September to January, but generally only once every three years for a given section of buffer, and no more than $50 \%$ of the annual production is removed (D.A. Haukos, oral commun., 2005). By late summer, most birds have completed their nesting cycles, thus nest failures due to management activities are minimized. Indeed, Berthelsen and Smith (1995) found that the peak of nest initiation for nongame grassland birds in the Texas SHP was mid-May; $50 \%$ had been initiated by 5 June and $95 \%$ had been initiated by 7 July. If seasonal priorities conflict, a rotational management approach may be one way of managing such conflicts.

Although the effects of management practices on avian communities are still debated, the outcomes may depend on which bird species are involved, the time of year when management takes place, the intensity/duration/frequency of management efforts, and the resulting vegetative structure. Under certain circumstances, controlled grazing in grasslands can promote greater avian species 
richness and nesting densities (e.g., Ignatiuk and Duncan, 2001; Renfrew and Ribic, 2001; Murphy and others, 2004).

\section{Avian Use of Grasslands As It May Relate to Playa Buffers}

The number of publications reporting effects of buffer design on wildlife diversity and density are few. Furthermore, nearly all such work has focused on riparian buffers or aquatic organisms that use the wetland itself (e.g., fish, aquatic invertebrates). In a review of wildlife values of buffers, Castelle and others (1994) reported that buffer widths intended to enhance or preserve wildlife diversity typically ranged from $<10$ to $98 \mathrm{~m}$. The lower end of that range of buffer widths was primarily for protecting small stream channels from thermal extremes, which can diminish the diversity of riparian fish and aquatic invertebrates (Castelle and others, 1994).

Most studies evaluating avian responses to restored grasslands in agricultural settings have focused on CRP fields or CRP-associated wetlands (e.g., Berthelsen and Smith, 1995; Delisle and Savidge, 1997; Best and others, 1997, 1998). Only two studies specifically addressed avian use of grass buffers installed to protect wetlands (Bryan and Best, 1991; Renfrew and Ribic, 2001); both studies were conducted in grassed waterways (GWs) in croplands of Iowa and Wisconsin. Below, we discuss several papers describing avian use of predominantly native shortgrass CRP fields in, or partially in, the PLR. However, bird use of CRP fields may not be instructive for predicting potential bird use of native, warm-season grasses in playa buffers because most original CRP fields were planted in non-native, cool-season grasses, and CRP fields are generally much larger, less linear patches of habitat than playa buffers are likely to be. Consequently, ecological processes, particularly predator dynamics and edge effects, are likely to be quite different in playa buffers versus CRP fields.

\section{Avian Densities in Grass Buffers}

Renfrew and Ribic (2001) evaluated the effects of grazing on avian community structure in a variety of habitat types, including 10-m-wide grass buffers planted between riparian areas and soybean fields and grazed pastures. Birds were rarely-to-never detected in the buffer strips, apparently because buffer grasses were too dense. Rather, birds used rotationally and conventionally grazed pastures where the percent cover of vegetation litter corresponded with densities of nesting bird.

Bryan and Best (1991) found that avian species richness and abundance were clearly greater in GWs of non-native, cool season tallgrasses than in the adjacent crop fields (soy beans). The GWs ranged from 9-30 m wide, a similar range of values reported as being adequate in many regions of minimal slope for significantly reducing most sediments from runoff. Overall, more bird species and more individual birds (48 and 2,198, respectively) were detected in GWs than in crop fields (14 and 682 , respectively). Several of the more common species were grassland species of concern, including Grasshopper Sparrow (Ammodramus savannarum) and Dickcissel (Spiza americana). Species that nested in the GWs included Ring-necked Pheasant (Phasianus colchicus), Sedge Wren (Cistothorus platensis), Common Yellowthroat Yellowthroat (Geothlypis trichas), Western Meadowlark (Sturnella neglecta), Red-winged Blackbird (Agelaius phoeniceus), Dickcissel, Grasshopper Sparrow, Vesper Sparrow (Pooecetes gramineus), Field Sparrow (Spizella pusilla), Song Sparrow (Melospiza melodia), and American Goldfinch (Carduelis tristis).

\section{Avian Densities in CRP Fields of the Playa Lakes Region}

General patterns in avian use of CRP fields have emerged from the studies described in further detail below. First, CRP plantings of short- and mid-height grasses, as well as native forbs, in the PLR are attractive to grassland birds and can promote high nesting densities and chick survival. Second, landscapes characterized by a greater ratio of CRP to cropland attract more nesting and 
wintering birds. In general, CRP plantings far outweigh croplands in their value to birds, suggesting that buffers can also provide habitat for many avian species.

Studies that present specific information on avian densities in CRP fields in the PLR are presented here.

- Berthelsen and others $(1989,1990)$. Studied the production of pheasants and waterfowl in CRP fields of the Texas SHP and estimated the number of pheasant chicks produced per year at 370/100 ha. Similar calculations for ducklings resulted in an estimate of 1,426 ducklings/year (6.3 nests/100 ha). Male pheasant recruitment in the fall was estimated at $0.87 / \mathrm{ha}$, and female recruitment in spring was $0.51 / \mathrm{ha}$. Pheasant nest density ranged from 1.18-2.1/ha, but did not vary by cover type. The authors concluded that the CRP cover types used in the Texas SHP compose good nesting habitat for pheasants.

- Berthelsen and Smith (1995). Estimated nesting densities and nest success of nongame birds in the same CRP fields of the study listed above. The dominant nesting species in CRP included Grasshopper Sparrow (0.6 nests/ha), Cassin's Sparrow (Aimophila cassinii) (0.3 nests/ha), Red-winged Blackbird (0.6 nests/ha), and Western Meadowlark (0.2 nests/ha).

- King and Savidge (1995). Evaluated the contribution of CRP lands to relative abundance and densities of wildlife species (including some birds) in southeastern Nebraska. They counted wildlife in high-percent CRP areas (18-21\% of the land in CRP) and in lowpercent CRP (2-3\% of the land was in CRP). Bird densities were measured in four cover types: (1) cool-season grasses $<3$ years old, warm-season grasses $<3$ years old, sorghum cropland, and established prairie $>10$ years old. In spring, Ring-necked Pheasants were more abundant in high-percent CRP areas; in summer, species richness and bird densities were lower in cropland. In winter, the warm-season grasses hosted the greatest number of individuals, largely due to vegetation height and visual obstruction.

- Best and others (1997). Compared avian use of 3- to 5-year-old CRP fields to avian use in reduced-tillage, rowcrop fields of six midwestern states, including two playa states (Kansas and Nebraska). Overall, the number of avian species detected in CRP versus rowcrop fields was similar; however, average annual avian abundance (mean number of birds recorded $/ \mathrm{km}$ of transect) was 1.4 to 10.5 times greater in CRP than in crop fields. The most common nesting species (no/km of transect) in Kansas were Ring-necked Pheasant (0.10), Northern Bobwhite (Colinus virginianus) (0.22), Mourning Dove (Zenaida macroura) (0.27), Grasshopper Sparrow (0.47), Dickcissel (4.31), Red-winged Blackbird (0.24), and Brown-headed Cowbird (Molothrus ater) (1.10). In Nebraska, the most common nesting species were Ring-necked Pheasant (0.31), Mourning Dove (0.27), Grasshopper Sparrow (2.48), Dickcissel (8.10), meadowlark species (0.33), and Brownheaded Cowbird (1.35). Overall, the number of nesting species and nests was significantly greater in CRP than in crop fields (3.5 and 13.5 times greater, respectively). Nesting success was similar in CRP and crop fields, but the number of young fledged from nests in CRP was 15 times that of nests in crop fields, respectively.

- Best and others (1998). Compared avian communities in CRP versus row-crop fields over three winters. Comparable study sites were located in Nebraska and five states outside of the PLR; CRP was composed of either permanent, non-native grasses/legumes or permanent, native grasses, although mixtures varied by state. Six to 32 bird species were detected in CRP fields, while 8-18 species were in crop fields. Average bird abundance per winter ranged from $0.1-5.1 / \mathrm{km}$ of transect in CRP fields, and from $0.1-24.2 / \mathrm{km}$ of transect in crop fields. CRP fields supported relatively high numbers of several species 
undergoing population declines, including Northern Bobwhite, Northern Harrier (Circus cyaneus), and Eastern Meadowlark (Sturnella magna).

- Other studies. The remaining studies we found on avian use of playa habitats were limited to species that primarily use the playa wetlands themselves, particularly emergent and moist-soil vegetation, mudflats, and water (i.e., waterfowl and shorebirds), and dry basins (e.g., Ring-necked Pheasants and Mourning Doves) (Nelson and others, 1983b; Quinlan and Baldassarre, 1984; Fischer and Bolen, 1991; Haukos and Smith, 1994; Iverson and others, 1995; Davis and Smith, 1998; Anderson and others, 2000; Ray and others, 2003; Conway and others, 2005).

Dillaha and others (1986) indicated that VFSs are unlikely to provide suitable wildlife habitat, as wildlife typically prefer stem densities and percent ground cover too sparse for adequately retarding runoff. However, the applicability of this paradigm in the PLR remains untested. Most studies of VFSs have employed tall, sod-forming grasses planted at high stem densities. If native short- and mid-height grasses dominate in most playa buffers, grass density and percent ground cover may not be problematic for wildlife. Bare ground was more extensive in CRP fields dominated by native short- and mid-height grasses in Kansas and Nebraska (Best and others, 1997).

A comprehensive understanding of avian use of playa buffers requires knowledge of how birds, and their predators, use the entire landscape. Many studies regarding avian use of wetlands have focused on the wetlands themselves or a limited set of microhabitat features. Recently, however, researchers have viewed wetland species within the context of the 'bigger picture' (Skagen and Knopf, 1994; Skagen, 1997; Fairbain and Dinsmore, 2001). While smaller-scale studies are also important, a hierarchical approach to scaling research will generate a much more complete picture of avian habitat needs as they pertain to buffers within their respective contexts.

A potential concern regarding the use of buffers for isolated wetlands is that they will represent not only small habitat fragments in a highly agriculturalized region, they will be relatively narrow, linear strips of habitat as well. Although it is generally thought that predation pressures are greater in highly fragmented landscapes and in small fragments, it appears these relationships are more complex that previously believed (e.g., Friesen and others, 1999; Chalfoun and others, 2002; Patten and Bolger, 2003; Skagen and others, 2005) and that predators differ in their responses to habitat fragmentation (Chalfoun and others, 2002).

In a literature review of the values to wildlife---especially birds---of conserved and restored habitats in fragmented landscapes, Marzluff and Ewing (2001) present a number of best approaches for restoring habitats. Those that may apply most to playa scenarios include (1) re-establishing and maintaining native vegetation and maximizing foliage-height diversity, (2) managing the landscapes that surround habitat fragments, (3) designing buffers that minimize damage from surrounding landuses, and (4) giving regulatory protection to entire complexes of small wetlands. Marzluff and Ewing (2001) also state that expectations for species conservation within habitat fragments must be realistic, that there are some species for which small fragments will not be suitable.

\section{Buffer Effectiveness for Reducing Human Disturbance}

The majority of research pertaining to vegetative buffers for minimizing human disturbance to wildlife has been limited to tall, woody buffers, often including dense screens of foliage. We found no literature that specifically addresses the effects of grass buffers on minimizing human disturbance. However, Milsap and Bear (2000) discuss spatial buffer zones for reducing disturbance to Burrowing Owls in Florida. The owl population $\left(6.9\right.$ pairs $\left./ \mathrm{km}^{2}\right)$ increased prior to residential development and began declining as the lot development reached $45-60 \%$ of the $36-\mathrm{km}^{2}$ study area. Nesting burrows buffered from disturbance by $>10 \mathrm{~m}$ resulted in greater numbers of young fledged than unbuffered nests, suggesting that spatial buffers provide a degree of protection from human disturbance for some 
species. Many aquatic and raptorial bird species, however, have much lower tolerances to disturbance (e.g., Skagen, 1991; Rodgers and Smith, 1997), and it is doubtful that grass buffers can offer much protection for them.

\section{Research Needs}

Basic ecological research is still needed in the PLR. This is particularly true for regions outside of the Texas SHP, as the majority of playa research has been conducted in the SHP. Until more work is completed, it will remain unclear how buffers for playas will affect ecological processes or vice versa. Thus, the list of research needs provided below pertains not only to buffers themselves, but also to the relationships between buffers and basic ecological processes.

Because a new stream of buffer funding has been made available, it is an excellent opportunity to dovetail buffer implementations with well-designed and replicated research studies. We strongly encourage a coordinated, regional approach to playa buffer research. This will mean incorporating scientists from all relevant disciplines, including hydrology, soil science, zoology, botany, entomology, agricultural engineering, buffer modeling, and geospatial mapping. The cooperation and assistance of land managers and private landowners will be needed not only for implementing and managing BMPs (including buffers), but also for helping field scientists collect buffer-monitoring data. We also emphasize the need to collect pre-treatment data to the extent possible. Without that fundamental basis for comparison, it will be difficult to determine the real effects of buffers. Because buffer research in real-world applications is the next major step in conducting buffer research, carefully planned field research on buffers in playa systems could contribute significantly to the overall knowledge of buffer design, effectiveness, and wildlife use.

A number of scientists with whom we spoke about research needs for buffers in the PLR indicated that bird research should not be conducted in a vacuum. Non-avian wildlife and plants are integral elements not only in local and regional ecologies, but in avian survivorship and productivity. The extent to which buffers will affect, or be affected by, other taxa should be incorporated into overall research approaches. In addition, research on playa buffers should be conducted at several scales: (1) landscape (e.g., SHP, Rainwater Basin, etc.), (2) entire complexes of playas affected by similar environmental characteristics and/or land-uses (e.g., cotton farming on fine-textured soils), and (3) individual watersheds (including not only the buffer and surrounding uplands, but also the playa basins and wetlands).

We initiate this list of research needs by posing questions included in a research proposal "Evaluation of grass buffer strips used to conserve playa wetlands," by D.A. Haukos (U.S. Fish and Wildlife Service), and James D. Ray (Texas Parks and Wildlife Department), both of whom have a strong interest and background in ecology of SHP playas. The proposed project was to dovetail with a buffer installation project that Haukos initiated in the Texas SHP in 2002.

a) How does native vegetation affect the sediment-, nutrient-, and pesticide-trapping efficiency of playa buffers? What is the rate of precipitation runoff, and to what extent does it transport sediment, nitrogen, phosphorus, herbicides (triazines), and insecticides (aldicarb and organochlorines)?

b) How do buffer width and type (including plant species) influence buffer effectiveness?

c) How does vegetation structure (including height, stem density, species) influence the sediment-, nutrient-, and pesticide-trapping efficiency of playa buffers?

d) How do slope and land-use (e.g., rangeland, cotton cropping, dryland wheat farming) affect buffer effectiveness?

e) To what extent do playa buffers increase overall wildlife diversity (birds, mammals, amphibians) and density (including nesting density)? 
These research questions cover a significant number of the potential research questions raised or implied in much of the playa and buffer literature. Additional research questions or needs are listed below.

\section{Buffer Effectiveness}

1. Buffer-effectiveness models are promising, but more work is needed to improve them and validate them in the field. Better predictive capabilities are needed to determine the optimal proportion of watershed area to filter width for given a set of variables, such as slope, soil structure, antecedent soil moisture, watershed cover type (e.g., crop residue), buffervegetation species, etc.

2. Past research on buffer effectiveness has focused on indirect measures, such as reductions in runoff volume and amounts of sediment trapped in buffers. Studies are now needed to quantify direct measures of sedimentation and pollution abatement that buffers provide for wetlands. To what extent do buffers actually diminish sedimentation rates and contaminants in buffered wetlands? How do those parameters compare to the same parameters measured in unbuffered wetlands or those with different buffer designs? How are direct measures affected by variations in rainfall intensity, antecedent soil moisture, soil porosity, slope, type of tillage, type of land-use?

3. Do buffers alter the ecological conditions and vegetation structure of playas through time? If so, how do these altered conditions influence biodiversity?

\section{Avian Responses to Buffers and Buffer Management}

1. What are the specific habitat requirements of nongame grassland species, and how can conservation plantings (including species, planting methods, size/shape, land-use context, management) promote the presence, and increase population growth rates, of declining grassland species? What are the survival rates, long-term productivity, and population trends of endemic, nongame grassland birds in the PLR, and how do buffer, CRP, and other conservation plantings affect them?

2. How do conservation plantings affect nesting densities of avian species considered agricultural pests (blackbirds) and/or parasites (cowbirds)? Which microhabitat features in conservation plantings encourage Red-winged Blackbirds and Brown-headed Cowbirds? The presence of waste corn in agricultural fields of the PLR has been implicated in population increases of geese, but more information is needed to elucidate this relationship.

3. Which management practices will be required for PLR buffers, and when and how often should they be managed? If rotational grazing is used to alter vegetative structure, how does the timing and stocking density affect nesting densities and productivity of grassland birds? Is burning a viable alternative, and, if so, when/how often should it take place and how will it affect avian communities using buffers, playa uplands, and playa basins?

4. How do large- or local-scale events (e.g., drought, haying or harvesting in nearby fields) affect monitoring results of playa buffers (e.g., how would harvesting winter wheat affect breeding bird communities in nearby buffers, and at what scale do the birds respond)? Can these phenomena be teased out from the real effects of buffers? What happens when buffers become inundated during very wet cycles?

\section{Basic Ecology of Species That Use Playa Systems}

1. Studies are needed to further define the basic functions and structures of playas, how they affect biodiversity, and how management may affect playa processes. Studies need to focus on 
natural food resources and native processes (e.g., natural flooding and drying regimes of playas) in playa habitats; how do they benefit the playa system overall? At what point does sedimentation become a problem, and what, if any restoration methods are appropriate for wetlands degraded by sedimentation? What are the ecological effects of differing land-uses and tillage practices on soil erosion and contaminants flowing into wetlands?

2. Evaluations of avian habitat use in isolated prairie wetlands must be conducted at the landscape scale as well as at smaller scales. How does fragmentation (e.g., small strips of native buffer habitat in the context of an agricultural landscape) affect predator communities, and how do predator communities in fragmented landscapes affect avian productivity?

3. What is the avian use of dry playas versus wet and frozen playas in winter, breeding season, and migration? How does use vary among passerines as well as shorebirds, waterfowl, waders, raptors?

4. In playa systems, what are the year-to-year variations in waterfowl nesting success/productivity, and how are those parameters affected by buffers, sedimentation/contaminants within nesting habitat? Which food resources are most crucial for hens and ducklings? What is the relative contribution of the PLR to overall duck populations in the Central Flyway?

5. What are the generation times and population turnover rates of aquatic and terrestrial invertebrates, during both flooding and drying cycles of playas? How do these invertebrate population dynamics affect overall avian communities using playa systems?

6. How are playa fish populations (none of which are native to playas) influencing or altering playa ecology (e.g., avian communities)? Do fish populations affect invertebrate and vegetation communities directly? If so, how do they affect overall food resources for birds? Does the presence of fish promote occurrences of piscivorous species that otherwise would not inhabit playa systems?

7. How do herbicides and other agrochemicals affect the productivity of all organisms using playa systems, including birds, amphibians, mammals, and invertebrates? Are herbicide/insecticide/fertilizer applications/effects different in different parts of the PLR, and, if so, how does that affect buffer needs (e.g., SHP versus Rainwater Basin)?

\section{Research Approaches}

1. Research studies regarding playas and buffers should be multidisciplinary and collaborative; in particular, more cooperation is needed among agricultural and conservation scientists, hydrologists and biologists.

2. Studies embedded in private lands would help stimulate landowner interest and future cooperation.

\section{Conclusions}

Overall, buffers can provide significant protection to wetlands from sediment and contamination runoff from the surrounding landscape. According to general patterns in the reviewed literature and expressed by playa scientists with whom we consulted, using native mixes of short to mid-height grasses would be a suitable starting point for buffers in most of the PLR. Buffer width will likely need to vary within the PLR, depending on slope, soil texture, land-use, and other considerations. Buffers of tall, stiff vegetation 10-60 m wide have been found reasonably effective for most uses in many regions that are wetter and have steeper slopes than the PLR, and buffer widths 
that fall within that range are likely to be effective in the PLR. Monitoring is needed to determine whether shortgrasses will be capable of handling the runoff velocities and depths typical of the PLR.

Developing buffer criteria for playas in different parts of the PLR will require the assistance of hydrologists, soil scientists, and other experts to evaluate the levels and types of threat in any one watershed or region. Modeling efforts may assist with predicting buffer effectiveness under different scenarios with respect to landscape variables and rainfall patterns typical of a given region with the PLR.

Buffers alone cannot solve all the runoff problems that affect wetlands. It will be critical to work with ranchers and farmers on BMPs with respect to minimizing the effects of insecticides, herbicides, nutrients, and other contaminants. Ideally, the BMPs should be developed and established before buffers are implemented, as non-buffer BMPs may dictate more precisely the buffer designs necessary for a given watershed.

Finally, significant additional research is needed to address the unknowns that will determine buffer effectiveness and longevity. Ideally, as buffers are established, they will become part of a large-scale, coordinated, ongoing research project that evaluates and compares buffer effectiveness for a given set of conservation objectives.

\section{Acknowledgments}

This project was conceived by the PLJV Monitoring, Evaluation, and Research Team, and the work was funded by PLJV and U.S. Geological Survey. We thank David Haukos, Art Allen, Brian Sullivan, Michael L. Dosskey, Alison Cariveau, Jim Ray, and Ted LaGrange for comments on earlier drafts of the manuscript and Mike Carter and Greg Esslinger for funding logistics. We are also grateful to the many people who provided information via e-mails and telephone calls.

\section{References Cited}

Abu-Zreig, M., 2001, Factors affecting sediment trapping in vegetated filter strips: Simulation study using VFSMOD: Hydrological Processes, v. 15, p. 1477-1488.

Abu-Zreig, M., Rudra, R.P., Whitely, H.R., Lalonde, M.N., and Kaushik, N.K., 2003, Phosphorus removal in vegetated filter strips: Journal of Environmental Quality, v. 32, p. 613-619.

Abu-Zreig, M., Rudra, R.P., Lalonde, M.N., Whiteley, H.R., and Kaushik, N.K., 2004, Experimental investigation of runoff reduction and sediment removal by vegetated filter strips: Hydrological Processes, v. 18, p. 2029-2037.

Anderson, J.T., and Smith, L.M., 2000, Invertebrate response to moist-soil management of playa wetlands: Ecological Applications, v. 10, p. 550-558.

Anderson, J.T., Smith, L.M., and Haukos, D.A., 2000, Food selection and feather molt by nonbreeding American green-winged teal in Texas playas: Journal of Wildlife Management, v. 64, p. 220-230.

Arora, K., Mickelson, S.K., Baker, J.L., Tierney, D.P., and Peters, C.J., 1996, Herbicide retention by vegetative buffer strips from runoff under natural rainfall: Transactions of the American Society of Agricultural Engineers, v. 39, p. 2155-2162.

Barfield, B.J., Blevins, R.L., Fogle, A.W., Madison, C.E., Inamdar, S., Carey, D.I., and Evangelou, V.P., 1998, Water quality impacts of natural filter strips in karst areas: Transactions of the American Society of Agricultural Engineers, v. 41, p. 371-381.

Baker, J.L., Mickelson, S.K., Hatfield, J.L., Fawcett, R., Hoffman, D.W., Franti, T.G., Peter, C.J., and Tierney, D.P., 1995, Reducing herbicide runoff: role of best management practices: Brighton Crop Protection Conference Proceedings, Brighton, England.

Berthelsen, P.S., Smith, L.M., and Coffman, C.L., 1989, CRP land and game bird production in the Texas High Plains: Journal of Soil and Water Conservation, v. 44:504-507. 
Berthelsen, P.S., and Smith, L.M., 1995, Nongame bird nesting on CRP lands in the Texas Southern High Plains. Journal of Soil and Water Conservation, v. 50, p. 672-675.

Best, L.N., Campa, H., III, Kemp, K.E., Robel, R.J., Ryan, M.R., Savidge, J.A., Weeks, Jr., H.P., and Winterstein, S.R., 1997, Bird abundance and nesting in CRP fields and cropland in the Midwest: a regional approach: Wildlife Society Bulletin, v. 25, p. 864-877.

Best, L.N., Campa, H., III, Kemp, K.E., Robel, R.J., Ryan, M.R., Savidge, J.A., Weeks, Jr., H.P., and Winterstein, S.R., 1998, Avian abundance in CRP and crop fields during winter months in the Midwest: American Midland Naturalist, v. 139, p. 311-324.

Black, A.L., and Aase, J.K., 1988, The use of perennial herbaceous barriers for water conservation and the protection of soils and crops: Agriculture, Ecosystems and the Environment, v. 22/23, p. $135-148$.

Boatman, N.D., and Sotherton, N.W., 1988, The agronomic consequences and costs of managing field margins for game and wildlife conservation: Aspects of Applied Biology, v. 17, p. 47-56.

Bolen, E.G., Smith, L.M., and Schramm, Jr., H.L., 1989b, Playa lakes: prairie wetlands of the southern High Plains: Bioscience, v. 39, p. 615-623.

Bowen, B.E., and A.D. Kruse, 1993, Effects of grazing on nesting by upland sandpipers in south central North Dakota: Journal of Wildlife Management, v. 57, p. 291-301.

Bryan, G.G., and Best, L.B., 1991, Bird abundance and species richness in grassed waterways in Iowa row-crop fields: American Midland Naturalist, v. 126, p. 90-102.

Bryant, F.C., and Smith, L.M., 1988, The role of wildlife as an economic input into a farming or ranching operation, in Mitchell, J.E., ed., Impacts of the Conservation Reserve Program in the Great Plains: symposium proceedings, September 16-18, 1987, Denver, Colorado. General Technical Report RM-158. U.S. Department of Agriculture, Forest Service, Rocky Mountain Forest and Range Experiment Station, Fort Collins, p. 95-98.

Bunn, J.A., 1997, The implications of alternative beliefs about soil-erosion-productivity relationships and conservation treatments for the economic dynamics of soil erosion on the southern Texas High Plains: Journal of Soil and Water Conservation, v. 52, p. 73-80.

Castelle, A.J., Johnson, A.W., and Conolly, C., 1994, Wetland and stream buffer size requirements -a review: Symposium on Wetland Processes and Water Quality, Minneapolis, Minnesota, 3-4 November 1992.

Chalfoun, A.D., Thompson, III, F.R., Ratnaswamy, M.J., 2002, Nest predators and fragmentation: a review and meta-analysis: Conservation Biology, v. 16, p. 306-318.

Conway, W.C., Smith, L.M., Ray, J.D., 2005, Shorebird habitat use and nest site selection in the playa lakes region: Journal of Wildlife Management, v. 69, p. 174-184.

Curtis, D., and Beierman, H., 1980, Playa lakes characterization study: U.S. Department of the Interior, Fish and Wildlife Service, Ecological Services Office, Fort Worth, Texas, 54 p.

Davis, C.A., and Smith, L.M., 1998, Ecology and management of migrant shorebirds in the Playa Lakes region of Texas: Wildlife Monographs, no. 140.

Delisle, J. M., and Savidge, J. A., 1997, Avian use and vegetation characteristics of Conservation Reserve Program fields: Journal of Wildlife Management, v. 61, p. 318-325.

Detenbeck, N.E., Elonen, C.M., Taylor, D.L., Cotter, A.M., Puglisi, F.A., and Sanville, W.D., 2002, Effects of agricultural activities and best management practices on water quality of seasonal prairie pothole wetlands: Wetlands Ecology and Management, v. 10, p. 335-354.

Dewald, C.L., Henry, J., Bruckerhoff, S., Ritchie, J., Dabney, S., Sheperd, D., Douglas, J., and Wolf, D., 1996, Guidelines for establishing warm season grass hedges for erosion control: Journal of Soil and Water Conservation, v. 51, p. 16-20.

Dillaha, T.A., 1989, Water quality impacts of vegetative filter strips: American Society of Agricultural Engineers Paper No. 89-2043, St. Joseph, Michigan.

Dillaha, T.A., 1990, Role of Best management practices in restoring the health of the Chesapeake Bay. In Perspectives on the Chesapeake Bay, 1990: Advances in Estuarine Sciences. 
CBP/TRS41/90. Chesapeake Bay Program, U.S. Environmental Protection Agency, Washington. DC. Available online at: <http://www.bse.vt.edu/Courses/BSE4324/Lecture11_BMPs Assessments\%20of\%20Effectiveness.html>.

Dillaha, T.A., Sherrard, J.H., and Lee, D., 1986, Long-term effectiveness and maintenance of vegetative filter strips: Virginia Water Resources Research Center, Bulletin 153, Blacksburg, 39 p.

Dillaha, T.A., Sherrard, J.H., and Lee, D., 1989a, Long-term effectiveness of vegetative filter strips: Water, Environment and Technology, v. 1, p. 419-421.

Dillaha, T.A., Reneau, R.B., Mostaghimi, S., and Lee, D., 1989b, Vegetative filter strips for agricultural nonpoint source pollution control: Transactions of the American Society of Agricultural Engineers, v. 32, p. 513-519.

Dosskey, M.G., 2001, Toward quantifying water pollution abatement in response to installing buffers on crop land: Environmental Management, v. 28, p. 577-598.

Dosskey, M.G., Schultz, R.C., and Isenhart, T.M., 1997, Riparian buffers for agricultural land. Agroforestry Notes, January 1997, no. 3. National Agroforestry Center, Lincoln, Nebraska.

Dvoracek, M.J., 1981, Modification of playa lakes in the Texas Panhandle, in Proceedings of the Playa Lakes Symposium, December 4-5, 1979, Arlington, Texas (Barclay, J.S., and White, Eds., W.V.,). Biological Services Project FWS/OBS-81/07. U.S. Fish and Wildlife Service Office of Biological Services, Washington, D.C., p. 64-82.

Eghball, B., Gilley, J.E., Kramer, L.A., and Moorman, T.B., 2000, Narrow grass hedge effects on phosphorus and nitrogen runoff following manure and fertilizer application: Journal of Soil and Water Conservation, v. 55, p.172-176.

Fairbain, S.E., and Dinsmore, J.J., 2001, Local and landscape-level influences on wetland bird communities of the Prairie Pothole Region of Iowa, USA: Wetlands, v. 21, p. 41-47.

Feldhake, C.M., and Boyer, D.G., 1995, Soil water depletion by $\mathrm{C}_{3}$ and $\mathrm{C}_{4}$ pasture grasses in central Appalachia. Journal of Soil and Water Conservation, v. 50, p. 106-109.

Fischer, D.H., and Bolen, E.G., 1981, Nestling diets of Red-winged and Yellow-headed Blackbirds on playa lakes of west Texas: The Prairie Naturalist, v. 13, p. 81-84.

Flickinger, E.L., Juenger, G., Roffe, T.J., Smith, M.R., and Irwin, R.J., 1991, Poisoning of Canada Geese in Texas by parathion sprayed for control of Russian wheat aphid: Journal of Wildlife Diseases, v. 27, p. 265-268.

Friesen, L., Cadman, M.D., and MacKay, R.J., 1999, Nesting success of Neotropical migrant songbirds in a highly fragmented landscape: Conservation Biology, v. 13, p. 338-346.

Gilley, J.E., Eghball, B., Kramer, L.A., and Moorman, T.B., 2000, Narrow grass hedge effects on runoff and soil loss: Journal of Soil and Water Conservation, v. 55, p. 190-196.

Guthery, F.S., and Stormer, F.A., 1984, Wildlife management scenarios for playa vegetation: Wildlife Society Bulletin, v. 12, p. 227-234.

Haukos, D.A., and Smith, L.M., 1992, Ecology of playa lakes. Waterfowl management handbook, leaflet 13.3.7. Department of Interior Fish and Wildlife Service, Washington, D.C., 6 p.

Haukos, D.A., and Smith, L.M., 1994, The importance of playa wetlands to biodiversity of the Southern High Plains: Landscape and Urban Planning, v. 28, p. 83-98.

Haukos, D.A., and Smith, L.M., 2003, Past and future impacts of wetland regulations on playa ecology in the Southern Great Plains: Wetlands, v. 23, p. 577-589.

Hayes, T.B., Collins, A., Lee, M., Mendoza, M., Noriega, N., Stuart, A.A., and Vonk, A., 2002, Hermaphroditic, demasculinized frogs after exposure to the herbicide atrazine at low ecologically relevant doses: Proceedings of the National Academy of Science, v. 99, p. 5476-5480.

Hoagland, B.W., and Collins, S.L., 1997, Heterogeneity of shortgrass prairie vegetation: the role of playa lakes: Journal of Vegetation Science, v. 8, p. 277-286.

Ignatiuk, J.B., and Duncan, D.C., 2001, Nest success of ducks on rotational and season-long grazing systems in Saskatchewan: Wildlife Society Bulletin, v. 29, p. 211-217. 
Inamdar, S.P., Sheridan, J.M., Williams, R.G., Bosch, D.D., Lowrance, R.R., Altier, L.S., and Thomas, D.L., 2000, Evaluation of the riparian ecosystem management model (REMM): I. Hydrology: Transactions of the American Society of Agricultural Engineers, v. 42, p. 1679-1689. Irwin, R.J., Connor, P.J., Baker, D., Didson, S, and Littlefield, C., 1996, Playa lakes of the Texas High Plains: a contaminants survey and assessment of biological integrity: U.S. Fish and Wildlife Service, Arlington, Texas, $94 \mathrm{p}$.

Iverson, G. C., Vohs, P.A., and Tacha, T. C., 1985, Habitat use by sandhill cranes wintering in western Texas: Journal of Wildlife Management, v. 49, p. 1074-1083.

Kemper, D., Dabney, S., Kramer, L., Dominick, D., and Keep, T., 1992, Hedging against erosion: Journal of Soil and Water Conservation, v. 47, p. 284-288.

King, J.W., and Savidge, J.A., 1995, Effects of the Conservation Reserve Program on wildlife in southeast Nebraska: Wildlife Society Bulletin, v. 23, p. 377-385.

King, L.D., 1981, Effects of swine manure lagoon sludge and municipal sewage sludge on growth, nitrogen, recovery, and heavy metal content of fescuegrass: Journal of Environmental Quality, v. 10 , p. 465-472.

Knisel, W.G., ed., 1980, CREAMS: A field-scale model for chemical, runoff, and erosion from agricultural management systems: Conservation Research Report, no. 26, US Department of Agriculture, Washington, D.C., 640 p.

Knopf, F.L., and Miller, B.J., 1994, Charadrius montanus -- montane, grassland, or bare-ground plover?: Auk, v. 111, p. 504-506.

Komor, S.C., and Hansen, D.S., 2003, Attenuation of runoff and chemical loads in grass filter strips at two cattle feedlots, Minnesota, 1995-1998. WRI no.03-4036. U.S. Department of the Interior, U.S. Geological Survey, Branch of Information Services, Denver, Colorado, 15 p. Available online at: <http://permanent.access.gpo.gov/waterusgsgov/water.usgs.gov/pubs/wri/wri03-4036/pdf/03-4036.book.pdf > . Accessed February 2005.

Lee, K-H., Isenhart, T.M., Schultz, R.C., and Mickelson, S.K., 1999, Nutrient and sediment removal by switchgrass and cool-season grass filter strips in Central Iowa, USA: Agroforestry Systems, v. 44, p. 121-132.

Leonard, R.A., Knisel, W.G., and Still, D.A., 1987, GLEAMS: Groundwater Loading Effects of Agricultural Management Systems: Transactions of the American Society of Agricultural Engineers, v. 30, p. 1403-1418.

Lin, H.S., McInnes, K.J., Wilding, L.P., and Hallmarl, C.T., 1998, Macroporosity and initial moisture effects on infiltration rates in vertisols and vertic intergrades: Soil Science, v. 163, p. 2-8.

Luo, H.R., Smith, L.M., Allen, B.L., and Haukos, D.A., 1997, Effects of sedimentation on playa wetland volume: Ecological Applications, v. 7, p. 247-252.

Luo, H.R., Smith, L.M., Haukos, D.A., and Allen, B.L., 1999, Sources of recently deposited sediments in playa wetlands: Wetlands, v. 19, p. 176-181.

Luckey, R.R., Gutentag, E.D., Heimes, F.J., and Weeks, J.B., 1988, Effects of future ground-water pumpage on the High Plains aquifer in parts of Colorado, Kansas, Nebraska, New Mexico, Oklahoma, South Dakota, Texas, and Wyoming: U.S. Department of the Interior, U.S. Geological Survey Professional Paper 1400-E, Washington, D.C.

Magette, W.L., Brinsfield, R.B., Palmer, R.E., and Wood, J.D., 1989, Nutrient and sediment removal by vegetated filter strips: Transactions of the American Society of Agricultural Engineers, v. 32, p. 663-667.

Marzluff, J.M., and Ewing, K., 2001, Restoration of fragmented landscapes for the conservation of birds: a general framework and specific recommendations for urbanizing landscapes: Restoration Ecology, v. 9, p. 280-292.

McKague, K.J., Cao, Y.Z., and Stephenson, D.E., 1996, The CREAMS model for evaluating the effectiveness of buffer strips in reducing sediment loads to wetlands, in Mulamootil, G., Warner, 
B.G., and McBean, E.A., eds., Wetlands: environmental gradients, boundaries, and buffers: CRC Press, Inc., Boca Raton, Florida, p. 251-261.

Melcher, C. P., and Skagen, S. K., 2005, Grass buffers for playas in agricultural landscapes: an annotated bibliography. Administrative Report prepared for Playa Lakes Joint Venture. U.S. Geological Survey, Fort Collins Science Center, Colorado, 75 p.

Mickelson, S.K., Boyd, P., Baker, J.L., and Ahmed, S.I., 2001, Tillage and herbicide incorporation effects on residue cover, runoff, erosion, and herbicide loss: Soil and Tillage Research, v. 60, p. 55-66.

Milsap, B.A. and Bear, C., 2000, Density and reproduction of burrowing owls along an urban development gradient: Journal of Wildlife Management, v. 64, p. 33-41.

Misra, A.K., Baker, J.L., Mickelson, S.K., and Shang, H., 1996, Contributing area and concentration effects on herbicide removal by vegetative buffer strips: Transactions of the American Society of Agricultural Engineers, v. 39, p. 2105-2111.

Mitchell, F., 2002, Shoreland buffers: protecting water quality and biological diversity (New Hampshire). Chapter II.1 in France, R.L., ed., Handbook of water sensitive planning and design: CRC Press LLC, Boca Raton, Florida, 699 p.

Miyasaka, S.C., and Habte, M., 2001, Plant mechanisms and mycorrhizal symbioses to increase phosphorus uptake efficiency: Communications in Soil and Plant Analysis, v. 32, p. 1101-1147.

Murphy, G.P., and Shaw, D.R., 1997, Effects of vegetative filter strip width on reducing fluometuron and norflurazon losses in surface runoff: Mississippi Agricultural Forestry Experiment Station Bulletin 214, Mississippi State, Mississippi.

Murphy, R.K., Schindler, D.J., and Crawford, R.D., 2004, Duck nesting on rotational and continuous grazed pastures in North Dakota: The Prairie Naturalist, v. 36, p. 83-94.

Nelson, R.W., Logan, W.J., and Weller, E.C., 1983a, Playa-wetlands and wildlife on the Southern Great Plains: a characterization of habitat: Biological Services Project FWS/OBS-83/28, U.S. Fish and Wildlife Service, Albuquerque, NM, 163 p.

Nelson, R.W., Logan, W.J., and Weller, E.C., 1983b, Playa-wetlands and wildlife on the Southern Great Plains: a guide to habitat management: Biological Services Project FWS/OBS-83/29, U.S. Fish and Wildlife Service, Washington, D.C., 99 p.

Natural Resource Conservation Service, 2005, NRCS conservation practice standards. Natural Resource Conservation Service, U.S. Department of Agriculture. Available online at: $<$ http://www.nrcs.usda.gov/technical/Standards/nhcp.html>, $<$ http://www.nrcs.usda.gov/technical/efotg/>. Accessed February 2005.

Patten, M.A., and Bolger, D.T., 2003, Variation in top-down control of avian reproductive success across a fragmentation gradient: Oikos, v. 101, p. 479-488.

Patty, L., Réal, B., and Gril, J.J., 1997, The use of grass buffer strips to remove pesticides, nitrate and soluble phosphorus compounds from runoff water: Pesticide Science, v. 49, p. 243-251.

Qiu, Z., 2003, A VSA-based strategy for placing conservation buffers in agricultural watersheds: Environmental Management, v. 32, p. 299-311.

Quinlan, E. A., and Baldassarre, G. A., 1984, Activity budgets of nonbreeding Green-winged Teal on playa lakes in Texas: Journal of Wildlife Management, v. 48, p. 838-845.

Ray, J. D., Sullivan, B. D., and Miller, H. W., 2003, Breeding ducks and their habitats in the High Plains of Texas: Southwestern Naturalist, v. 48, p. 241-248.

Reed, E.L., 1930, Vegetation of the playa lakes in the staked plains of western Texas: Ecology, v. 11, p. 597-600.

Renfrew, R.B., and Ribic, C.A., 2001, Grassland birds associated with agricultural riparian practices in southeastern Wisconsin: Journal of Range Management, v. 54, p. 546-552.

Rickerl, D.H., Jansen, L.L., and Woodland, R., 2000, Buffered wetlands in agricultural landscapes in the Prairie Pothole region: environmental, agronomic, and economic evaluations: Journal of Soil and Water Conservation, v. 55, p. 220-225. 
Robinson, C.A., Ghaffarzadeh, M., and Cruse, R.M., 1996, Vegetation filter strips effects on sediment concentration in cropland runoff: Journal of Soil and Water Conservation, v. 50, p. 227230.

Rocke, T.E., and Samuel, M.D., 1999, Water and sediment characteristics associated with avian botulism outbreaks in wetlands: Journal of Wildlife Management, v. 63, p. 1249-1260.

Rodgers, Jr., J.A., and Smith, H.T., 1997, Buffer zone distances to protect foraging and loafing waterbirds from human disturbance in Florida: Wildlife Society Bulletin, v. 25, p. 139-145.

Sauer, T.J., and Daniel, T.C., 1987, Effect of tillage systems on runoff losses of surface applied pesticides: Journal of the Soil Science Society of America, v. 51, p. 410-415.

Schmitt, T.J., Dosskey, M.G., and Hoagland, K.D., 1999, Filter strip performance and processes for different vegetation, widths, and contaminants: Journal of Environmental Quality, v. 28, p. 1479_ 1489.

Seybold, C., Merise, W., and Delorem, D., 2001, Removal and degradation of atrazine and metolachlor by vegetative filter strips on clay loan soil: Communications in Soil and Plant Analysis, v. 32, p. 723-737.

Sharpley, A.N., Kleinman, P., and McDowell, R., 2001, Innovative management of agricultural phosphorus to protect soil and water resources: Communications in Soil Science and Plant Analysis, v. 32, p. 1071-1100.

Shaw, D.R., and Webster, E.P., 1994, Impact of grass filter strips on herbicide loss in runoff from soybeans: Technical Completion Report Project G2028-05. Water Resource Research Institute, Mississippi State University, Mississippi State, 19 p.

Skagen, S. K., 1997, Stopover ecology of transitory populations: the example of migrating shorebirds: Ecological Studies, v. 125, p. 244-269.

Skagen, S.K., and Knopf, F.L., 1994, Migrating shorebirds and habitat dynamics at a prairie wetland complex: Wilson Bulletin, v. 106, p. 91-105.

Skagen, S.K., Knight, R.L., and Orians, G.H., 1991, Human disturbance of an avian scavenging guild: Ecological Applications, v. 1, p. 215-225.

Smith, L.M., 2003, Playas of the Great Plains: University of Texas Press, Austin, p. 166-173.

Sprague, M.A., and Triplett, G.B., eds., 1986, No-tillage and surface-tillage agriculture: the tillage revolution: John Wiley \& Sons, New York, 467 p.

Stoecker, A., Mathia, G.A., Cardwell, H.T., and Knight , A., 1981, Economic consequences of playa lake enhancements for wildlife, in Proceedings of the Playa Lakes Symposium, 4-5 December 1979, Arlington, Texas. Office of Biological Services, U.S. Department of the Interior Fish and Wildlife Service, Washington , D.C., p. 112-123.

Stubbendiek, J., Hatch, S.L., and Kjar, K.J., 1981, North American range plants ( $2^{\text {nd }}$ ed.): University of Nebraska Press, Lincoln, 464 p.

Thurman, E.M., Bastian, K.C., and Mollhagen, T., 2000, Occurrence of cotton herbicides and insecticides in playa lakes of the High Plains of West Texas: Science of the Total Environment, v. 248, p. 189-200.

Tingle, C.H., Shaw, D.R., Boyette, M., and Murphy, G.P., 1998, Metalachlor and metribuzin losses in runoff as affected by width of vegetation filter strips: Weed Science, v. 46, p. 475-479.

U.S. Department of Agriculture, 2000, Conservation buffers work... economically and environmentally: U. S. Department of Agriculture, Washington, DC.

van der Kamp, G., Stolte, W.J., and Clark, R.G., 1999, Drying out of small prairie wetlands after conversion of their catchments from cultivation to permanent brome grass: Hydrological Sciences Journal, v. 44, p. 387-397.

Van Dijk, P.M., Kwaad, F.J., and Klapwijk, M., 1996, Retention of water and sediment by grass strips: Hydrological Processes, v. 10, p. 1069-1080. 
White, D.H., King, K.A., and Prouty, R.M., 1980, Significance of organochlorine and heavy metal residues in wintering shorebirds and Corpus Christi, Texas, 1976-1977: Pesticide Monitoring Journal, v. 14, p. 58-63.

White, D.H., Mitchell, C.A., Wynn, L.D., Flickinger, E.L., and Kolbe, E.J., 1982, Organophosphate insecticide poisoning of Canada Geese in the Texas panhandle: Journal of Field Ornithology, v. 53, p. 22-27.

Whitson, T.D., Burrill, L.C., Dewey, S.A., Nelson, B.E., Lee, R.D., and Parker, R., 1996: Weeds of the West $\left(5^{\text {th }}\right.$ ed.): Pioneer of Jackson Hole, Jackson, Wyoming, 630 p.

Wilson, L.G., 1967, Sediment removal from flood water by grass filtration: Transactions of the American Society of Agricultural Engineers, v. 10, p. 35-37.

Wobeser, G., 1997, Avian botulism---another perspective: Journal of Wildlife Diseases, v. 33, p. 181-186.

Wood, W.W., and Sanford, W.E., 1994, Recharge to the Ogallala: 60 years after C.V. Theis' analysis, in Urban, L.V. and Wyatt, A.W., eds.: Proceedings of the Playa Basin Symposium, Water Resources Center, Texas Tech University, Lubbock, p. 23-33.

Wong, S.L., and McCuen, R.H., 1982, The design of vegetative buffer strips for runoff and sediment control: Maryland Coastal Zone Management Program, Civil Engineering Department, University of Maryland, College Park.

Wu, J., Mersie, W., Atalay, A., and Seybold, C.A., 2003, Copper retention from runoff by switchgrass and tall fescue filter strips: Journal of Soil and Water Conservation, v. 58, p. 67-73.

Zartman, R.E., Evans, P.W., and Ramsey, R.H., 1994, Playa lakes on the Southern High Plains in Texas: reevaluating infiltration: Journal of Soil and Water Conservation, v. 49, p. 299-301. 


\section{Appendix 1. Acronyms used in this document.}

$\mathrm{BCR}=$ Bird Conservation Region

$\mathrm{BMP}=$ best management practice

$\mathrm{CRP}=$ Conservation Reserve Program

$\mathrm{DN}=$ dissolved nitrogen

DNTE $=$ dissolved nitrogen-trapping efficiency

$\mathrm{DP}=$ dissolved phosphorus

DPTE $=$ dissolved phosphorus-trapping efficiency

$\mathrm{GW}=$ grassed waterways

HTE $=$ herbicide-trapping efficiency

$\mathrm{N}=$ nitrogen

NRCS = Natural Resource Conservation Service

NTE $=$ nitrogen-trapping efficiency

$\mathrm{OP}=$ organophosphate

$\mathrm{P}=$ phosphorus

PLJV = Playa Lakes Joint Venture

PLR = playa lakes region

$\mathrm{PTE}=$ phosphorus-trapping efficiency

SHP = Southern High Plains

STE $=$ sediment-trapping efficiency

TSS $=$ total suspended solids

$\mathrm{UN}=$ undissolved nitrogen

UNTE $=$ undissolved nitrogen-trapping efficiency

$\mathrm{UP}=$ undissolved phosphorus

UPTE $=$ undissolved phosphorus-trapping efficiency

VFS $=$ vegetated filter strip

$\mathrm{WR}=$ water retained/infiltrated 


\section{Appendix 2. Summary of selected buffer studies.}

A sample of studies conducted on design and effectiveness of buffers or vegetated filter strips (VFS) for trapping sediment, nitrogen, phosphorus, and herbicide by scientists that have published repeatedly on this topic or have published reviews or bibliographies on buffers or VFSs. Codes are listed again in alphabetical order in the footnotes.

\begin{tabular}{|c|c|c|c|c|c|}
\hline $\begin{array}{l}\text { Author, } \\
\text { year }\end{array}$ & Region & $\begin{array}{l}\text { Crop }^{a} \\
\text { tillage } \\
\text { type }\end{array}$ & Buffer designc & Buffer effectiveness $^{c}$ & Notes $^{c}$ \\
\hline $\begin{array}{l}\text { Abu-Zreig } \\
\text { and others } \\
(2004)\end{array}$ & $\begin{array}{l}\text { Ontario, } \\
\text { Canada }\end{array}$ & N/A & $\begin{array}{l}\text { VFSs in experimental } \\
\text { field plots } 2,5,10,15 \\
\text { m wide; slopes } 2.3, \\
5 \% \text {; VFS species } \\
\text { perennial ryegrass/ } \\
\text { fescue, trefoil/ } \\
\text { creeping red fescue, } \\
\text { bare, native riparian } \\
\text { vegetation (incl. wild } \\
\text { oat, quack, fescue, } \\
\text { dandelion, other); } \\
\text { tests of STE, WR. }\end{array}$ & $\begin{array}{l}\text { Ave. STE = 84\% (in trefoil/creeping red } \\
\text { fescue range }=68 \% \text { \& } 98 \% \text { in } 2-\& 15-\mathrm{m} \text { VFS, } \\
\text { respectively; } 25 \% \text { in control); little } \\
\text { improvement beyond } 10 \mathrm{~m} \text {, indicating width } \\
\text { threshold for STE. WR = } 20 \% \text { \& } 62 \% \text { in } 2-\mathrm{m} \& \\
10-\mathrm{m} \text { VFSs, respectively. For } 5-\mathrm{m} \text { filters, WR } \\
=47 \% \text { in native, } 40 \% \text { in trefoil/creeping red } \\
\text { fescue; WR greater in native due to greater } \% \\
\text { cover. Greater antecedent soil-moisture } \\
\text { content = decreased WR. }\end{array}$ & $\begin{array}{l}\text { Soil type = silt loam (38\% sand, } \\
54 \% \text { silt, } 8 \% \text { clay); varied } \\
\text { antecedent soil-moisture; } \\
\text { simulated runoff representing } \\
\text { short/intense events over } 2-10 \\
\text { yrs; increasing runoff flow rate } \\
\text { decreased STE. }\end{array}$ \\
\hline $\begin{array}{l}\text { Barfield } \\
\text { and others } \\
\text { (1998) }\end{array}$ & Kentucky & $\begin{array}{l}\text { NT, CV } \\
\text { in the } \\
\text { year prior } \\
\text { to study; } \\
\text { no crop } \\
\text { grown } \\
\text { during } \\
\text { study }\end{array}$ & $\begin{array}{l}\text { VFSs of naturally } \\
\text { occurring bluegrass/ } \\
\text { fescue sod; VFSs } \\
4.57,9.14,13.72 \mathrm{~m} \\
\text { wide in } 4.57 \times 22.1 \mathrm{~m} \\
\text { field plots at } 9 \% \\
\text { slope. VFSs } 1-\mathrm{yr} \text { old; } \\
\text { tests of STE, NTE, } \\
\text { PTE, HTE. }\end{array}$ & $\begin{array}{l}\text { Overall effectiveness >than reported } \\
\text { elsewhere in similar plots \& on gentler slopes- } \\
\text {--probably due to significant infiltration in karst } \\
\text { soils, even when saturated. STE, NTE, PTE, } \\
\text { HTE increased with > buffer width, although } \\
\text { difference between } 4.57-\& 9.14-m \text { buffers } \\
\text { was not significant; overall buffer efficiency } \\
\text { >90\% for sediment and pollutants. Overall } \\
\text { reductions in pollutants attributed more to } \\
\text { infiltration than soil adsorption. }\end{array}$ & $\begin{array}{l}\text { Simulated } 2 \text { 10-yr rainfall events. } \\
\text { Region dominated by karst soils } \\
\text { underlain by limestone (i.e., } \\
\text { >>macropore structure, infiltration } \\
\text { capacity) at significant slopes; } \\
\text { included here to provide a sharp } \\
\text { contrast to conditions of the PLR. } \\
\text { Rainfall applied only upslope of } \\
\text { buffers (not on buffers). }\end{array}$ \\
\hline $\begin{array}{l}\text { Castelle } \\
\text { and others } \\
(1994)\end{array}$ & $\mathrm{N} / \mathrm{A}$ & $\mathrm{N} / \mathrm{A}$ & $\begin{array}{l}\text { Buffer review. } \\
\text { Authors identified } 4 \\
\text { criteria for assigning } \\
\text { buffer width: the } \\
\text { protected resource's } \\
\text { functional value, } \\
\text { intensity of land-use } \\
\text { in the watershed, } \\
\text { buffer characteristics, } \\
\text { specific buffer } \\
\text { purpose. }\end{array}$ & $\begin{array}{l}\text { Buffers 3-200 m. Effectiveness for a given } \\
\text { width varied according to conditions; overall, } \\
\text { buffers of } \geq 15 \text { m usually needed under most } \\
\text { conditions. Narrower buffers needed when: } \\
\text { buffer in good condition (native vegetation, } \\
\text { undisturbed soils), wetland severely } \\
\text { damaged/of low value, watershed has low- } \\
\text { impact land-use. Wider buffers needed when: } \\
\text { valuable/functional wetlands are threatened, } \\
\text { watershed receives intensive land-use, when } \\
\text { buffer in poor condition. }\end{array}$ & $\begin{array}{l}\text { This is a literature review of buffer } \\
\text { effectiveness. Overall, flow rates } \\
\text { lower when sheeting over even } \\
\text { surface, greater when } \\
\text { channelized. Buffers remove } \\
\text { nutrients and metals through } \\
\text { plant uptake, infiltration, settling } \\
\text { of suspended solids. }\end{array}$ \\
\hline
\end{tabular}




\begin{tabular}{|c|c|c|c|c|c|}
\hline $\begin{array}{l}\text { Dillaha and } \\
\text { others } \\
(1986)\end{array}$ & $\begin{array}{l}\text { Various, } \\
\text { mostly e. } \\
\text { US }\end{array}$ & N/A & $\begin{array}{l}\text { Review of numerous } \\
\text { studies in } \\
\text { experimental \& field } \\
\text { plots, all VFS. Focus } \\
\text { on STE, NTE, PTE. }\end{array}$ & $\begin{array}{l}\text { STE generally } \geq 90 \% \text { for larger sediments \& } \\
<40 \% \text { for clay }<1 \mathrm{~m} \text { if flow was even \& } \\
\text { shallow; wider VFSs needed for finer } \\
\text { particles, deeper flow. VFSs tended to } \\
\text { become inundated by sediments at upslope } \\
\text { flanks, diminishing effectiveness. DPTE \& } \\
\text { DNTE = generally }>50<70 \% \text { in VFSs }<1 \text { to } \\
36 \mathrm{~m} \text {, but some studies show no difference } \\
\text { between controls \& VFS plots. }\end{array}$ & $\begin{array}{l}\text { Includes literature review \& } \\
\text { Virginia VFS specs. VFS } \\
\text { management emphasized. If VFS } \\
\text { in good shape, overall STE } \\
\text { overall excellent for sand- to silt- } \\
\text { sized particles, less for clay. PTE } \\
\text { and NTE of VFSs less effective, } \\
\text { even in VFSs } \sim 30-36 \mathrm{~m} \text {, partly } \\
\text { due to chemical changes of N } \% \\
P \text { in VFS resulting in later release } \\
\text { of N, P. }\end{array}$ \\
\hline $\begin{array}{l}\text { Dillaha and } \\
\text { others } \\
(1989 a)\end{array}$ & Virginia & N/A & $\begin{array}{l}\text { VFSs } \sim 3-9 \text { m, mostly } \\
\text { tall fescue. Field } \\
\text { evaluations of real- } \\
\text { world buffers. }\end{array}$ & $\begin{array}{l}33 \text { farms were visited; } 76 \% \text { had functional } \\
\text { buffers being used for the intended purpose, } \\
\text { but nearly } 100 \% \text { were damaged by fully } \\
\text { erosion, thus largely ineffective. Some were } \\
\text { also damaged by cattle trampling, farm } \\
\text { equipment, lack of maintenance. }\end{array}$ & $\begin{array}{l}\text { This was a field evaluation of } \\
\text { actual VFSs installed on farms. } \\
\text { The authors provide installation } \\
\text { and maintenance } \\
\text { recommendations, although some } \\
\text { may unsuitable for the PLR. }\end{array}$ \\
\hline $\begin{array}{l}\text { Dillaha and } \\
\text { others } \\
(1989 b)\end{array}$ & Virginia & $\mathrm{CV}$ & $\begin{array}{l}\text { VFSs } 4.6,9.1 \text { m wide } \\
\text { in field plots; slope } 5- \\
\text { 16\%; tests of STE, } \\
\text { NTE, PTE. }\end{array}$ & $\begin{array}{l}\text { Significantly more STE, NTE, PTE in plots w/ } \\
\text { VFS, all three increasing with filter width. STE } \\
=70-84 \% \text { (ave. } 70 \% \text { ), NTE = 54-73\%, PTE = } \\
61-79 \% \text {. Percent N and P reduced closely } \\
\text { corresponded with sediment reduction, as } \\
\text { most N \& P were sediment-bound. After } \\
\text { subsequent rainfalls, sediment-bound P \& N } \\
\text { began dissolving, volitalizing (gaseous state), } \\
\text { \& were released at levels high enough to } \\
\text { cause eutrophication in buffered wetland. On } \\
5 \% \text { slopes, VFSs absorbing concentrated } \\
\text { flows generally as effective as those w/ even } \\
\text { flows, \& more effective than VFSs absorbing } \\
\text { even flows on } 16 \% \text { slopes; similar trends } \\
\text { observed for P \& N. Concentrated flows had } \\
\text { proportionately smaller volumes of sediments } \\
\text { by the time they had concentrated, thus } \\
\text { sediment volume not necessarily greater in } \\
\text { concentrated flows. }\end{array}$ & $\begin{array}{l}\text { Silt loam soils. N \& P applied, } \\
\text { then rainfall simulated at } 50 \\
\mathrm{~mm} / \mathrm{hr} 4 \text { times over one week } \\
\text { ( } 200 \mathrm{~mm}) \text {; runoff in even } \\
\text { sheetflow or concentrated in } \\
\text { drainageways. Most sediment } \\
\text { deposited just upslope, or in first } \\
\text { few meters, of the VFSs. As } \\
\text { sediments buried VFS upper } \\
\text { flanks, they spilled downslope to } \\
\text { the next section until that was } \\
\text { buried; VFSs became less } \\
\text { effective with each new rainfall; } \\
\text { may not be a problem in real } \\
\text { watersheds if vegetation can grow } \\
\text { up through accumulated } \\
\text { sediments. }\end{array}$ \\
\hline
\end{tabular}




\begin{tabular}{|c|c|c|c|c|c|}
\hline $\begin{array}{l}\text { Eghball } \\
\text { and others } \\
(2000)\end{array}$ & Iowa & $\begin{array}{l}\text { CV, NT; } \\
\text { CR }\end{array}$ & $\begin{array}{l}\text { 6-yr. old single } \\
\text { switchgrass hedges, } \\
0.75 \text { m wide planted } \\
\text { in } 6 \text {-ha field plots. } \\
\text { Applications of } \\
\text { commercial fertilizer } \\
\& \text { manures on no-till } \\
\text { and disked plots with } \\
\text { varying levels of corn } \\
\text { residue; tests of NTE } \\
\text { and PTE. }\end{array}$ & $\begin{array}{l}\text { NTE \& PTE were significantly greater with } \\
\text { than without hedges, but they may have been } \\
\text { more effective on slopes < } 12 \% \text {. More P ran } \\
\text { off from manure fields than those treated w/ } \\
\text { commercial fertilizer, although a smaller \% of } \\
\text { applied P was lost from manure fields. More N } \\
\text { ran off fertilized fields. Overall, hedges were } \\
\text { effective in reducing N to acceptable levels; } \\
\text { but DPTE was still higher than desired. }\end{array}$ & $\begin{array}{l}\text { Ave. slope }=12 \% \text { (range } 8-16 \% \text { ) } \\
\text { w/ silt loam soils. Rainfall }(6.4 \\
\mathrm{cm} / \mathrm{hr} \text { for } 2 \text { hrs.) was simulated. } \\
\text { Residue cover in no-till plots was } \\
51-94 \% \text { (ave. } 79 \% \text { ), } 11-58 \% \text { on } \\
\text { disked plots (ave. } 34 \% \text { ). }\end{array}$ \\
\hline $\begin{array}{l}\text { Gilley and } \\
\text { others } \\
(2000)\end{array}$ & $\begin{array}{l}\text { Same as } \\
\text { above }\end{array}$ & $\begin{array}{l}\text { Same as } \\
\text { above }\end{array}$ & Same as above & $\begin{array}{l}\text { Where water ponded deeply, runoff began to } \\
\text { filter unevenly through the hedge. In no-till } \\
\text { plots, runoff and soil loss was } 52 \& 53 \% \text { less, } \\
\text { respectively, from plots w/ corn residue \& } \\
\text { hedges than from plots w/ no residue \& } \\
\text { hedges; in disked plots, runoff and soil loss } \\
\text { was } 22 \& 57 \% \text { less in plots w/ residue \& } \\
\text { hedges than in from plots with no hedges. In } \\
\text { disked plots w/ hedges but no residue, runoff } \\
\text { and soil loss were } 41 \& 63 \% \text { less in plots w/ } \\
\text { no hedges or residue. }\end{array}$ & $\begin{array}{l}\text { This was another part of the study } \\
\text { listed above. STE was reported in } \\
\text { tons/ha rather than the more- } \\
\text { typical \%, making comparisons } \\
\text { with this study difficult. Runoff } \\
\text { was measured in mm. It } \\
\text { underscores the need to use } \\
\text { hedges in conjunction with other } \\
\text { BMPs. }\end{array}$ \\
\hline $\begin{array}{l}\text { Komor and } \\
\text { Hansen } \\
(2003)\end{array}$ & $\begin{array}{l}\text { Minne- } \\
\text { sota }\end{array}$ & N/A & $\begin{array}{l}\text { VFSs to reduce } \\
\text { runoff at } 2 \text { feedlots: } \\
35 \text { cattle, } 225 \text { cattle. }\end{array}$ & $\begin{array}{l}\text { Pollutant reduction ranged widely due to } \\
\text { variation in season, soil-moisture, extent of } \\
\text { matting of filter grasses. DNTE = 14-75\%, } \\
\text { UNTE \& organic N = 29-82\%, UPTE = 24- } \\
82 \%, \text { DPTE = 14-72\%. Also, reductions of: } 6- \\
79 \% \text { dissolved chloride, }-3-82 \% \text { dissolved } \\
\text { sulfate, } 33-80 \% \text { dissolved ammonia N } \\
\text { (>>volitalized or taken up by plants), 30-81\% } \\
\text { of the chemical oxygen demand, and } 18-79 \% \\
\text { fecal coliform bacteria (also killed by exposure } \\
\text { to sunlight). }\end{array}$ & $\begin{array}{l}\text { Affects of cattle \# not mentioned } \\
\text { explicitly, but results similar at } \\
\text { both feedlots/VFSs. Ground water } \\
\text { compromised by infiltration of } \\
\text { pollutants from VFSs. Primary } \\
\text { means of pollutant reduction } \\
\text { believed to be interception by } \\
\text { plants \& soil, but also by } \\
\text { infiltration \& plant uptake. }\end{array}$ \\
\hline $\begin{array}{l}\text { Lee, K.-H. } \\
\text { and others } \\
(1999)\end{array}$ & & & $\begin{array}{l}\text { VFSs } 3 \text { and } 6 \text { m wide } \\
\text { (ratios of watershed } \\
\text { to VFS = 40:1 \& 20:1, } \\
\text { respectively), planted } \\
\text { w/ switchgrass, } \\
\text { smooth brome, } \\
\text { timothy, and/or } \\
\text { fescue; tests of STE, } \\
\text { NTE, PTE. }\end{array}$ & $\begin{array}{l}\text { 6-m STE = 77\%, NTE = 46\%, DNTE = 42\%, } \\
\text { PTE = 52\%, DPTE = 43\%. 3-m STE = 66\%, } \\
\text { NTE = 28\%, DNTE = 25\%, PTE = 37\%, DPTE } \\
=34 \% . \text { Overall, 6-m VFSs significantly more } \\
\text { effective. Switchgrass VFSs significantly more } \\
\text { effective at removing N, DN, P, DP than cool- } \\
\text { season grasses. }\end{array}$ & $\begin{array}{l}\text { Simulated rainfall at varying } \\
\text { intensity/duration. Ave. slopes } \\
3 \% \text {. }\end{array}$ \\
\hline
\end{tabular}




\begin{tabular}{|c|c|c|c|c|}
\hline $\begin{array}{l}\text { Magette } \\
\text { and others } \\
(1989)\end{array}$ & $\begin{array}{l}\text { Mid- } \\
\text { Atlantic } \\
\text { coastal } \\
\text { plain }\end{array}$ & $\begin{array}{l}\text { VFSs of fescue } 4.6 \& \\
9.2 \mathrm{~m} \text { wide in field } \\
\text { plots }(5.5 \times 22 \mathrm{~m}) \\
\text { tests of STE, NTE, } \\
\text { PTE. }\end{array}$ & $\begin{array}{l}\text { Overall, increasing ratio of VFS area to } \\
\text { unvegetated (runoff) area increased VFS } \\
\text { effectiveness. VFSs had better STE than NTE } \\
\text { or PTE; overall effectiveness for all NTE/PTE } \\
\text { diminished w/ subsequent rainfall events. NTE } \\
\text { in } 4.6-m \text { VFSs was poor, likely because } \\
\text { soluble N is transported easily in terrestrial } \\
\text { systems; possible lower threshold of VFS } \\
\text { width, below which N cannot be removed } \\
\text { effectively. Most P bound to sediment, thus } \\
\text { transport generally occurs w/ suspended } \\
\text { solids; if VFS has high STE, it should have } \\
\text { high PTE. }\end{array}$ & $\begin{array}{l}\text { Simulated rainfall applied; bare } \\
\text { source areas tilled 2X during } 12 \\
\text { tests of varying antecedent } \\
\text { moisture conditions/rainfall } \\
\text { intensities; nutrient sources = } \\
\text { liquid N v. chicken manure. } \\
\text { Results varied widely, partly due } \\
\text { to 'flushing' events where mass } \\
\text { losses of built-up material } \\
\text { suddenly occurred. }\end{array}$ \\
\hline $\begin{array}{l}\text { Mickelsen } \\
\text { and Baker } \\
\text { (1993) }\end{array}$ & & $\begin{array}{l}\text { VFSs } 4.6 \& 9.1 \mathrm{~m} \\
\text { wide; tests of STE. }\end{array}$ & STE $=72 \& 76 \%$, respectively. & $\begin{array}{l}\text { Lower STE that that in Dillaha } \\
\text { and others }(1989 b) \text { probably due } \\
\text { to greater sediment volumes in } \\
\text { runoff in this study. }\end{array}$ \\
\hline $\begin{array}{l}\text { Robinson } \\
\text { and others } \\
(1996)\end{array}$ & lowa & $\begin{array}{l}\text { VFSs on slopes } 7 \& \\
12 \% \text { in field plots, } \\
18.3 \text { m of tilled fallow } \\
\text { as runoff source, } 18.3 \\
\text { m VFS of brome (w/ } \\
\text { some alfalfa, orchard- } \\
\text { grass); tests of STE. }\end{array}$ & $\begin{array}{l}\text { STE of first } 3 \mathrm{~m}=70 \%, 85 \% \text { in } 9,1 \mathrm{~m}, \mathrm{w} / \mathrm{most} \\
\text { sediment having been trapped by } 9.1 \mathrm{~m} \text {; } \\
\text { nonlinear relationship. Runoff and sediment } \\
\text { losses greater on } 12 \% \text { slopes. }\end{array}$ & $\begin{array}{l}\text { Silt loam soils, natural rainfall. } \\
\text { Storm intensity (rainfall amount) } \\
\text { affected width at which maximum } \\
\text { STE was achieved. }\end{array}$ \\
\hline $\begin{array}{l}\text { Schmitt } \\
\text { and others } \\
(1999)\end{array}$ & $\begin{array}{ll}\text { East- } & \text { N/A } \\
\text { central } & \\
\text { Nebraska } & \end{array}$ & $\begin{array}{l}\text { Filter strips } 7.5 \& 15 \\
\text { m wide; tests of } \\
\text { STE, HTE, NTE, } \\
\text { PTE; in field plots of } \\
\text { grain sorghum, } \\
\text { soybeans; some } \\
\text { strips contained } \\
\text { shrubs, trees. }\end{array}$ & $\begin{array}{l}\text { Doubling VFS width } 7.5 \text { to } 15 \text { m doubled } \\
\text { infiltration, dilution. Herbicide reduced mostly } \\
\text { by dilution from rainfall; infiltration reduced } \\
\text { runoff } 36-82 \% \text {. }\end{array}$ & $\begin{array}{l}\text { Slopes ranged } 6-7 \% \text {, soils were } \\
\text { silty clay loam. }\end{array}$ \\
\hline
\end{tabular}




\begin{tabular}{|c|c|c|c|c|c|}
\hline $\begin{array}{l}\text { Seybold } \\
\text { and others } \\
(2001)\end{array}$ & $\mathrm{N} / \mathrm{A}$ & N/A & $\begin{array}{l}\text { VFSs planted w/ } \\
\text { switchgrass } 125 \mathrm{~cm} \\
\text { high (at tillering } \\
\text { stage) in tilted beds } \\
(0.9 \times 3 \mathrm{~m}) \text { at } 1 \% \\
\text { slope; tests of HTE } \\
\text { for atrazine and } \\
\text { metolachlor. }\end{array}$ & $\begin{array}{l}\text { Overall HTE in VFS plots = 68.5-73\%, in bare } \\
\text { plots = 52.9-57.9\%. Infiltration/ leaching was } \\
\text { primary means of HTE; at all soil depths, } \\
\text { microbial activity degraded herbicides } \\
\text { continuously over 7-week study; degradation } \\
\text { rates were greater in VFSs than in bare strips, } \\
\text { significantly for metolachlor. Dissolved } \\
\text { herbicide in surface runoff reduced by soil \& } \\
\text { plant adsorption greater in bare plots (6.2- } \\
6.4 \% \text { ) than VFS plots (5.3-5.4\%). Infiltration } \\
56 \% \text { in bare strips, } 82 \% \text { in VFSs. (Infiltration } \\
\text { in sandy loams is likely to occur at a steadier } \\
\text { rate, but overall infiltration predicted to be } \\
\text { greater in clay loams; however, infiltration in } \\
\text { clay loams may be reduced by cracks that can } \\
\text { form during wet-dry cycles; see Vervoort and } \\
\text { others (1999.) Two of three VFSs precluded } \\
\text { all runoff; ave. runoff from bare plots = 33\%. }\end{array}$ & $\begin{array}{l}\text { Clay loam soil. Herbicides tested } \\
\text { commonly used on corn. } \\
\text { Switchgrass selected due to stiff } \\
\text { stalk that resists high water } \\
\text { velocities, deep root system } \\
\text { capable of soil-holding, has } \\
\text { minimal water/nutrient } \\
\text { requirements. HTE depends on } \\
\text { soil type/texture, vegetation type, } \\
\text { slope, antecedent soil-moisture, } \\
\text { rainfall, macropores, etc. Roots of } \\
\text { switchgrass may degrade } \\
\text { metolachlor more efficiently than } \\
\text { atrazine, but half-life of atrazine } \\
\text { may be } 2.5-4 \text { times longer. Mersie } \\
\text { and others (1999) found that } \\
\text { switchgrass VFSs removed } \\
\text { significantly more atrazine and } \\
\text { metolachlor than bare strips; } \\
\text { Tingle and others (1998) found } \\
\text { significantly more metolachlor } \\
\text { was removed by fescue VFSs } \\
\text { than bare strips. In field settings, } \\
\text { switchgrass thatch buildup } \\
\text { expected to enhance adsorption. }\end{array}$ \\
\hline $\begin{array}{l}\text { Tingle and } \\
\text { others } \\
(1998)\end{array}$ & $\begin{array}{l}\text { Missis- } \\
\text { sippi }\end{array}$ & $\begin{array}{l}\mathrm{SB} ; \\
\mathrm{CV}\end{array}$ & $\begin{array}{l}\text { VFSs of } 0.5,1,2,3,4 \mathrm{~m} \\
\text { wide in } 4 \times 22 \mathrm{~m} \text { field plots } \\
\text { planted } \mathrm{w} / \text { tall fescue, } \\
\text { clipped to } 10 \mathrm{~cm} \text { at start of } \\
\text { growing season for } 3 \text { yrs; } \\
\text { tests of HTE for metolachlor } \\
\& \text { metribuzin. }\end{array}$ & $\begin{array}{l}\text { HTE }=48-68 \% 2 \mathrm{~d} \text { after application, } \\
\text { regardless of VFS width; more metolachlor } \\
\text { removed than metribuzin. After } 84 \mathrm{~d} \text {, more } \\
\text { herbicide lost in every plot, but reductions in } \\
\text { VFS plots higher than in controls, \& 4-m plots } \\
\text { overall had best HTE. Cumulative sediment \& } \\
\text { runoff reduction }=83 \& 46 \% \text {, respectively, } \\
\text { width not significant.. }\end{array}$ & $\begin{array}{l}\text { Silty clay soil. } 2 \text { days after first } \\
\text { herbicide treatment } 83-93 \% \text { water } \\
\text { runoff reduced, regardless of } \\
\text { width; } 46-77 \% \text { reduction of water } \\
\text { over growing season. Both } \\
\text { metolachlor \& metribuzin highly } \\
\text { soluble. }\end{array}$ \\
\hline $\begin{array}{l}\text { Wilson } \\
\text { (1967) }\end{array}$ & Arizona & & $\begin{array}{l}\text { VFSs } 167.5 \& 305 \text { m wide } \\
\text { in field plots } 0.3 \text { and } 4.54 \\
\text { acres, respectively; slopes } \\
.6 \text { and } .1 \% \text {, respectively; } 3 \\
\text { yrs.; tests of STE \& WR } \\
\text { w/in flood periods. }\end{array}$ & $\begin{array}{l}\text { VFSs effective for STE of sand, silt, and clay } \\
\text { (inverse relationship between STE of particle } \\
\text { size \& VFS width). STE greatest in first } 15.4 \\
\text { m, but depths continued to increase up } \\
\text { through } \sim 121 \text { m. Overall STE = } 60-95 \% \text {, } \\
\text { generally better in Bermudagrass. }\end{array}$ & $\begin{array}{l}\text { VFSs = fescue, switchgrass, } \\
\text { Bermudagrass, Sudan grass, or } \\
\text { alfalfa (>1 variety of switchgrass, } \\
\text { orchardgrass, Bermudagrass). } \\
\text { Max. sand STE at } 3.5 \mathrm{~m} \text {, silt at } \\
15.4 \mathrm{~m} \text {, and clay at } 91.5 \mathrm{~m} \text {. } \\
\text { Overall, grass not inhibited by } \\
\text { deposits; Bermudagrass esp. able } \\
\text { to 'climb' out of sediments. }\end{array}$ \\
\hline
\end{tabular}


${ }^{\mathrm{a}}$ Crops: $\mathrm{CR}=$ corn; $\mathrm{CT}=$ cotton; $\mathrm{SB}=$ soybean; $\mathrm{WW}=$ winter wheat; $\mathrm{IR}=$ irrigated; $\mathrm{DR}=$ dryland farming

${ }^{b}$ Tillage: $\mathrm{CV}=$ conventional; $\mathrm{NT}=$ no-till

${ }^{\mathrm{c}} \mathrm{DN}=$ dissolved nitrogen

DNTE $=$ dissolved nitrogen-trapping efficiency

$\mathrm{DP}=$ dissolved phosphorus

DPTE $=$ dissolved phosphorus-trapping efficiency

$\mathrm{HTE}=$ herbicide-trapping efficiency

NTE $=$ nitrogen-trapping efficiency

PTE $=$ phosphorus-trapping efficiency

STE $=$ sediment-trapping efficiency

$\mathrm{UN}=$ undissolved nitrogen

$\mathrm{UNTE}=$ undissolved nitrogen-trapping efficiency

$\mathrm{UP}=$ undissolved phosphorus

UPTE $=$ undissolved phosphorus-trapping efficiency

$\mathrm{WR}=$ water retained/infiltrated 